\title{
Targeting MERTK and AXL in EGFR Mutant Non-Small Cell Lung Cancer
}

\author{
Dan Yan ${ }^{1}$, H. Shelton Earp ${ }^{2,3}$, Deborah DeRyckere ${ }^{1}$ (D) and Douglas K. Graham ${ }^{1, *}$ \\ 1 Aflac Cancer and Blood Disorders Center, Children's Healthcare of Atlanta, Department of Pediatrics, Emory \\ University, Atlanta, GA 30322, USA; dyan2@emory.edu (D.Y.); deborah.deryckere@emory.edu (D.D.) \\ 2 UNC Lineberger Comprehensive Cancer Center, Department of Medicine, Chapel Hill, NC 27599, USA; \\ shelton_earp@med.unc.edu \\ 3 Department of Pharmacology, School of Medicine, University of North Carolina at Chapel Hill, \\ Chapel Hill, NC 27599, USA \\ * Correspondence: Douglas.Graham@choa.org
}

Citation: Yan, D.; Earp, H.S.;

DeRyckere, D.; Graham, D.K

Targeting MERTK and AXL in EGFR Mutant Non-Small Cell Lung Cancer. Cancers 2021, 13, 5639.

https://doi.org/

10.3390/cancers13225639

Academic Editor: Noriaki Sunaga

Received: 18 October 2021

Accepted: 10 November 2021

Published: 11 November 2021

Publisher's Note: MDPI stays neutral with regard to jurisdictional claims in published maps and institutional affiliations.

Copyright: (c) 2021 by the authors. Licensee MDPI, Basel, Switzerland. This article is an open access article distributed under the terms and conditions of the Creative Commons Attribution (CC BY) license (https:/ / creativecommons.org/licenses/by/ $4.0 /)$.
Simple Summary: Expression of MERTK and/or AXL (members of the TAM family of receptor tyrosine kinases) provides a survival advantage for non-small cell lung cancer (NSCLC) cells and correlates with lymph node metastasis, drug resistance, and disease progression. TAM receptors on host tumor infiltrating cells also play important roles in the immunosuppressive tumor microenvironment. Thus, MERTK and AXL are attractive biologic targets for NSCLC treatment, and clinical trials have recently been launched exploring the efficacy of MERTK/AXL inhibitors in NSCLC. This timely review will address the potential clinical impact of these agents as well as potential side effects to be monitored with the use of these novel drugs.

Abstract: MERTK and AXL are members of the TAM family of receptor tyrosine kinases and are abnormally expressed in $69 \%$ and $93 \%$ of non-small cell lung cancers (NSCLCs), respectively. Expression of MERTK and/or AXL provides a survival advantage for NSCLC cells and correlates with lymph node metastasis, drug resistance, and disease progression in patients with NSCLC. The TAM receptors on host tumor infiltrating cells also play important roles in the immunosuppressive tumor microenvironment. Thus, MERTK and AXL are attractive biologic targets for NSCLC treatment. Here, we will review physiologic and oncologic roles for MERTK and AXL with an emphasis on the potential to target these kinases in NSCLCs with activating EGFR mutations.

Keywords: MERTK; AXL; TAM family; receptor tyrosine kinase; targeted therapy; NSCLC; EGFR mutation

\section{Introduction}

Despite intensive efforts over many years, lung cancer remains difficult to treat and is still the leading cause of cancer-related death in both men and women worldwide. Therapeutic regimens for lung cancer have traditionally been based on tumor histology and morphology. Lung cancers are divided into two broad categories: non-small cell lung cancer (NSCLC) and small cell lung cancer (SCLC). These NSCLCs account for $85 \%$ of all lung cancers, and are further subtyped into adenocarcinoma (Ad-NSCLC, $40 \%$ ), squamous cell carcinoma (SqNSCLC, 25-30\%), and large cell carcinoma (LCC, 5-10\%) [1-4]. Although surgery is regarded as the best treatment choice for early-stage and locally advanced NSCLC [2,5], only 20-25\% of NSCLC tumors are suitable for curative resection [6]. Over 50\% of patients are diagnosed with metastasis [7] and these patients traditionally have dismal survival with a high rate of recurrence after resection [8-11]. Conventional, highly cytotoxic, platinum-based chemotherapies remain the cornerstone of treatment in the advanced setting, resulting in an increase in median survival by only 1.5 months relative to supportive care [12]. Treatment goals for patients with recurrent and metastatic disease are to extend life and maintain quality of life; obviously, there is a critical need for more efficacious therapies [13]. As the 
5-year overall survival rate decreases from $68 \%$ in patients with stage IB disease to less than $10 \%$ in patients with stage IVA-IVB disease $[2,14]$, early detection, particularly for high risk patients, may also enhance survival.

Following clinical validation of translational inhibitors targeting two important NSCLC oncogenic drivers, epidermal growth factor receptor (EGFR) [15-18] and anaplastic lymphoma kinase (ALK) [19-21], molecular-targeted therapies have been applied to the management of metastatic NSCLC, resulting in remarkably improved prognosis and quality of life relative to patients treated with conventional chemotherapeutics [22-24]. Additional mutated oncogenic proteins have been identified in NSCLC, including HER2, BRAF, RET, $M E T$, and ROS1 [20,25]. Even though patients respond to targeted therapies initially, the majority of patients, if not ultimately all patients, relapse within 1 to 2 years when treated with targeted therapies [26-30]. Therefore, understanding the mechanisms of primary and secondary resistance to current targeted therapies is critical to enhance patient outcomes. New therapeutic approaches will be required to further enhance outcomes. Both MERTK and AXL, members of the TAM (TYRO3, AXL, and MERTK) family of receptor tyrosine kinases (RTK), are emerging therapeutic targets in NSCLC. This review will highlight both the survival role for these RTKs in tumor cells and the physiologic, anti-inflammatory functions that are subverted in the tumor microenvironment. Thus, MERTK and AXL targeting may have a dual therapeutic action in NSCLC. The potential to target MERTK and AXL in mtEGFR-expressing NSCLC to improve clinical outcomes will also be discussed.

\section{Physiologic Roles for MERTK and AXL}

The TAM kinases are structurally unique from other RTK subfamilies, possessing two immunoglobulin-like (Ig) repeats and two fibronectin type III (FNIII) domains in their extracellular region and a conserved intracellular kinase domain with an unusual signature sequence, KW(I/L)A(I/L)ES [31,32] (Figure 1A). Growth Arrest Specific 6 (GAS6) and Protein S (PROS1) are the two best characterized ligands for TAM receptors, although other TAM ligands have been reported including TUBBY [33], Tubby-like protein 1 (TULP-1) [33], and Galectin-3 (LGALS3) [34]. Structurally, both GAS6 and PROS1 contain a N-terminal glutamic acid-rich (Gla) domain, followed by four epidermal growth factor (EGF)-like repeats, and a C-terminal sex hormone binding globulin (SHBG) homology domain comprised of two globular laminin G-like domains (2-LG) [35] (Figure 1B). The Gla domain confers the ability of these ligands to bind phosphatidylserine (PtdSer) through their $\mathrm{N}$ termini. The complex physiologic role of this signaling system is in part defined by this PtdSer sensing which, for example, recognizes the billions of cells that die by apoptosis in the human body daily. However, GAS6 and PROS1 bind differentially to the TAM receptors. MERTK and TYRO3 are activated by both GAS6 and PROS1, while AXL is only activated by GAS6 [36,37]. In the absence of apoptotic cells or PtdSer, the affinity of GAS6 for AXL is more than 6-fold higher than for TYRO3 and 70-fold higher than for MERTK [37-39] (Figure 1C). GAS6 binding to both MERTK and TYRO3 is enhanced in the presence of PtdSer, while AXL binding is not stimulated. 
A

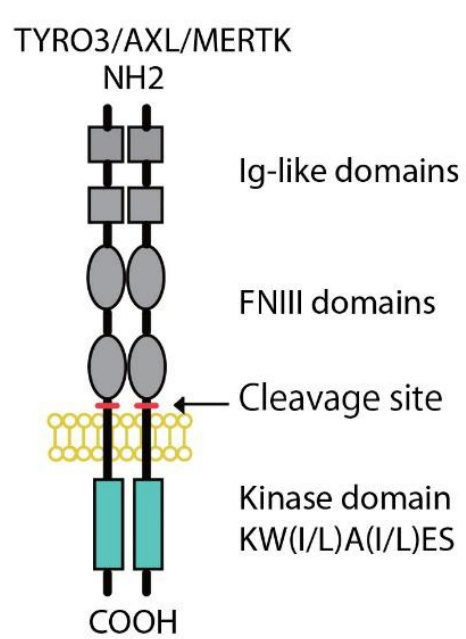

B

PROS1/GAS6

$\mathrm{NH} 2$

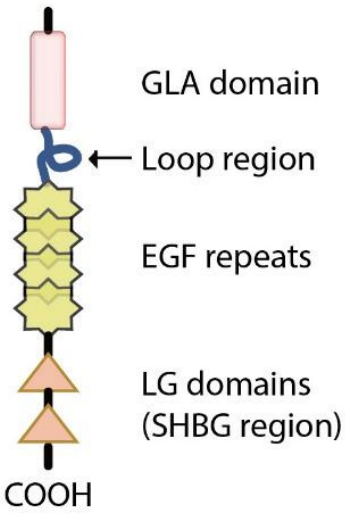

C

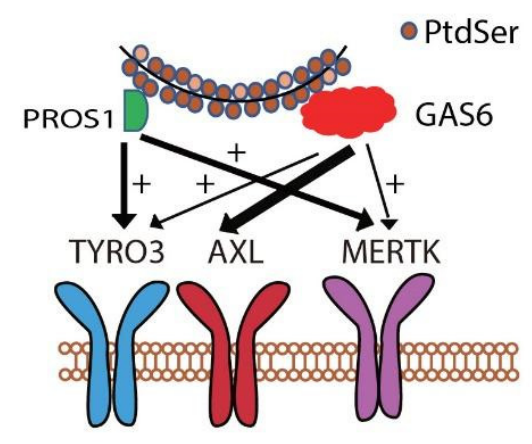

Figure 1. TAM receptors and their ligands. (A) TAM receptors TYRO3, AXL, and MERTK share a similar structure of two immunoglobulin (Ig)-like domains, two fibronectin type III (FNIII) domains, and an intracellular kinase domain. (B) GAS6 and PROS1 contain a $\gamma$-carboxyglutamic acid (Gla) domain, four EGF-like domains, and two lamine G (LG)-like domains. (C) Interaction of TAM receptors with their ligands GAS6 and PROS1. The thickness of the arrows indicates the binding strengths of each ligand to the TAM receptors. "+" indicates the enhanced signal in the presence of phosphatidylserine (PtdSer).

Although TAM receptors are expressed in embryonic tissues [32,40,41], triple knockout mice are viable without obvious developmental defects at birth [42], indicating that TAM receptors are not required for embryogenesis. However, knockout of single and/or all 3 TAM receptors is associated with diverse phenotypes in mice, including impaired clearance of apoptotic cells [43], enlarged spleen [44], increased inflammation [45], impairment of tumor cell killing by NK cells [46], hyperproliferation of B and T cells [42], hyperactivation of antigen-presenting cells [42], increased autoantibody production [42,43,47,48], autoimmunity [48], defects in platelet aggregation [49], aborted spermatogenesis and germ cell death [44], neurological abnormalities [44], multiple organ defects, and blindness in adult triple knockout mice [44]. Many of these consequences of TAM receptor loss are related to apoptotic cell clearance and post receptor anti-inflammatory action. This knowledge has spurred research to define the role of TAM RTKs as innate immune checkpoint genes (i.e., guardians against persistent or inappropriate inflammation). Absence of MERTK expression is associated with increased DC activation upon encounter with apoptotic cells, resulting in upregulation of costimulatory molecules and T cell activation [50]. Although some of these phenotypes were noted with knockout of single TAM receptor, they are much more pronounced in triple TAM knockout mice, indicating at least some overlap in TAM kinase functions $[43,44,49]$.

\section{Oncogenic Roles for MERTK and AXL}

\subsection{Roles in NSCLC}

MERTK and AXL are frequently aberrantly expressed in NSCLC patient samples, but are absent or expressed at low levels in normal human bronchial epithelial cells [51-58]. High levels of AXL have been described in subsets of both treatment-naïve and relapsed NSCLC [58-60]. Increased AXL expression was associated with increased tumor cell invasiveness and tumor grade and predicted poorer survival in patients with NSCLC [56,57,61-65]. Inhibition of MERTK in NSCLC cell lines with a small molecule MERTK tyrosine kinase inhibitor (TKI), MERTKspecific blocking monoclonal antibody, or shRNA induced apoptosis and decreased colony formation in vitro and inhibited tumor growth in vivo [66-69]. Treatment with an antibody against active AXL or siRNA/shRNA AXL knockdown also provided anti-tumor activity in NSCLC models $[56,64,70]$.

High levels of MERTK and/or AXL have also been implicated in drug resistance and radioresistance $[54,55,60,69,71-86]$. Increased MERTK or AXL expression in NSCLC 
correlated with chemotherapy resistance [51,66,70,87-89]. Conversely, MERTK or AXL knockdown, treatment with a MERTK monoclonal antibody, or AXL inhibitor R428 or MP470 promoted apoptosis and increased the sensitivity of NSCLC cells to chemotherapeutic agents [51,66,70,87-89]. Upregulated AXL and its interaction with EGFR were associated with resistance to $\mathrm{PI} 3 \mathrm{~K} \alpha$ inhibition due to sustained mTOR activation, and addition of AXL inhibitor R428 sensitized tumor cells to PI3K $\alpha$ [76]. In addition, AXL has been implicated in resistance to anti-IGF-1R therapy [90,91] and resistance to BRAF/MEK inhibitors [92]. Similarly, high levels of AXL protein were associated with resistance to ATR inhibition and treatment with AXL inhibitor R428 sensitized NSCLC cells to ATR inhibitors, VX-970 and AZD6738, resulting in significant DNA damage [59]. Further, AXL expression was associated with JAK1-STAT3 signaling in treatment-naïve tumors and lung cancer patientderived organoids with high levels of AXL and JAK1 were sensitive to combined treatment with AXL kinase inhibitor TP-0903 and JAK inhibitor ruxolitinib [93]. In addition, MERTK expression was increased when NSCLC cell lines were treated with AXL inhibitor or AXL expression was inhibited using siRNA and dual inhibition of AXL and MERTK reduced cell expansion in vitro and tumor growth in vivo [78]. These data implicate MERTK and/or AXL as potential therapeutic targets in NSCLC.

\subsection{Functions in Cancer Cells}

MERTK was cloned from a B ALL cell line cDNA library and is ectopically expressed in over $30-50 \%$ of childhood acute lymphoblastic leukemia samples and the majority of lymphoid leukemia cell lines, but was not expressed in normal T and B lymphocytes [32,94]. Similarly, AXL was originally cloned from chronic myelogenous leukemia patient samples but is not expressed in granulocytes or lymphocytes [31], suggesting upregulation in the context of hematopoietic malignancy. Both MERTK and AXL are expressed in a wide variety of human cancers, including NSCLC [51], melanoma [95], leukemia [96,97], breast [98], colon [99], liver [100], gastric [101], prostate [102,103], ovarian [104], and brain cancers $[105,106]$, where they promote tumor cell survival and/or proliferation and contribute to oncogenesis. Expression and stimulation of a chimeric MERTK protein in NIH3T3 cells was sufficient to confer anchorage-independent colony formation, a hallmark of oncogenic transformation [107]. Similarly, expression of MERTK conferred IL-3-independence in Ba/F3 cells [108,109]. These data suggest a tumor promoting role for MERTK. Similarly, overexpression of $A X L$ induced transformation of NIH3T3 cells and the resulting cells were tumorigenic in nude mice [31,110]. Although MERTK overexpression in normal lung epithelial cells was not sufficient to drive tumorigenesis in vivo, it promoted expansion of normal lung epithelial cells in culture and enhanced clonogenic potential [55].

TAM receptors, particularly AXL, have been associated with epithelial-mesenchymal transition (EMT) [87,111-114]. EMT is an important step in the development of metastatic disease in which cell-cell contacts are lost, leading to tumor cell migration, invasion, and metastasis, and has been associated with therapeutic resistance in NSCLC [87,115-119]. Aberrant expression of AXL promotes phenotypes associated with EMT and metastasis, and inhibition of AXL reduces indicators of EMT/metastasis in various cancers [65,112,120-122]. Ectopic overexpression of AXL in NSCLC cell lines caused increased filopodia formation, while silencing of endogenous AXL led to loss of spindle-like morphology [123]. NSCLC cells that express high levels of AXL generally expressed abundant vimentin, a transcriptional regulator that contributes to EMT phenotypes [87], and downregulation of AXL decreased expression of vimentin in NSCLC [74,87,112]. Further, ectopic expression of AXL increased migration and invasion in NSCLC cells and AXL inhibition reduced the invasive capacity of NSCLC cell lines $[61,64,123]$. Enhanced metastasis was accompanied by AXL-dependent MMP-9 activation [124]. Similarly, overexpression of MERTK promoted migration in both normal lung epithelial and NSCLC cell lines [55].

Cancer stem cells (CSCs) are a small subpopulation of self-renewing cells within the tumor that influence therapeutic resistance, recurrence, and metastasis [125,126]. Some reports suggest a role for TAM receptors in cancer stemness [125]. MERTK was upregulated 
in glioblastoma multiforme (GBM) stem-like cells and silencing of MERTK suppressed the self-renewal of patient-derived GBM stem-like cells [127]. Maintenance of the CSC phenotype was mediated by STAT3/KRAS/SRC signaling downstream of MERTK. AXL has also been linked to cancer stemness. Expression of $A X L$ positively correlated with expression of several stem cell genes (e.g., Isl1, Cdc2a, Bglap1, CD44, and ALDH1), resulting in tumorigenicity and chemoresistance $[65,122,128]$. Interestingly, expression of several other stem cell genes (e.g., Smad9, S100b, Mme and Col1a1) negatively correlated with expression of AXL. Similarly, knockdown of MERTK, but not AXL or TYRO3, up-regulated stemness-associated genes in dormant prostate cancer cells [129]. Thus, the TAM kinases may have varying roles in cancer stemness, and further study is needed to understand their specific roles in lung CSCs. Prostate CSCs expressed high levels of GAS6, suggesting that MERTK and/or AXL functions in cancer stem cells are related to their kinase activity [130].

\subsection{Signaling in Cancer Cells}

Activation of AXL and/or MERTK leads to signaling cascades that are important for tumor progression (Figure 2). MERTK kinase activity is associated with phosphorylation at three tyrosine residues: Y749, Y753, and Y754 on MERTK [131] and Y779, Y821, and Y866 on AXL [132,133]. Both Y779 and Y821 on AXL and two additional phosphorylation sites for MERTK (Y872 and Y929) are docking sites for GRB2 and the p85 regulatory subunit of PI3K, which activate MEK/ERK and PI3K/AKT signaling pathways, respectively [109,132,133]. The MEK/ERK signaling is associated with cell proliferation [134], while the PI3K/AKT pathway is preferentially involved in tumor cell survival [135]. MERTK-dependent cell migration is mediated by FAK signaling $[55,136]$, while MERTK induced transformation correlates with activation of STAT-dependent transcription [137]. The anti-apoptotic effects of MERTK also correlate with negative regulation of the pro-apoptotic tumor suppressor WW domain-containing oxidoreductase (Wwox) [138]. Also, AXL inhibition is reported to mediate apoptosis by reducing the expression of the anti-apoptotic protein MCL1 [139]. AXL dimerizes with and phosphorylates EGFR to promote activation of the PLC $\gamma$-PKCmTOR signaling cascade and tumor cell survival [76]. Similarly, there is crosstalk between MERTK and EGFR and they are frequently co-expressed on both mtEGFR- and wtEGFRexpressing NSCLC cell lines $[69,80]$. In fact, MERTK stabilized the EGFR protein on the cell surface, probably by preventing EGFR internalization and degradation, as EGF-dependent EGFR turnover was reversed by inhibition of lysosomal hydrolase activity [140]. Further, inhibition of MERTK expression using siRNA destabilized expression of EGFR protein.

\subsection{Immune Regulatory Functions in the Tumor Microenvironment}

MERTK is upregulated upon monocyte to macrophage differentiation [141-143]. Expression of MERTK and AXL on tumor-infiltrating macrophages polarizes them towards a pro-tumor M2-like phenotype [143-146]. M2 macrophages promote an immunosuppressive tumor microenvironment by increasing expression of wound-healing cytokines (IL-10, TGF $\beta$, and IL-4) and decreasing pro-inflammatory cytokines (IL-12, TNF $\alpha$, and IL-6) $[45,143,147-151]$ (Figure 3A). MERTK activation negatively regulates the secretion of pro-inflammatory cytokines, such as $\mathrm{TNF} \alpha$, through suppression of $\mathrm{NF} \kappa \mathrm{B}$ activation in macrophages [45,152]. LPS challenge led to over-produced TNF $\alpha$ in Mertk ${ }^{k d}$ mice, which lack the tyrosine kinase signaling domain, due to hyper-activation of NFKB [45,153]. Inhibition of MERTK by knockout of Mertk in mice, neutralization of TAM kinase signaling using a recombinant MERTK-Fc protein as a ligand sink or a GAS6 blocking antibody, and knockout of AXL in macrophages also impaired M2-macrophage anti-inflammatory phenotypes, decreased immunosuppressive IL-10 production, and increased pro-inflammatory IL-12 release $[86,143,154,155]$. These cytokine alterations lead to expansion of anti-tumor $\mathrm{CD}^{+} \mathrm{T}$ lymphocytes and inhibition of tumor growth and metastasis (Figure 3B). Indeed, inhibition of MERTK in the tumor microenvironment in $\mathrm{Mertk}^{-/}$- mice was sufficient to decrease tumor growth and metastasis [154]. MERTK-expressing dendritic cells can also regulate $\mathrm{T}$ cell activation directly [156]. Blocking MERTK on dendritic cells using 
anti-MERTK antibody promoted T cell proliferation, while treatment with a MERTK-Fc protein to mimic the effect of MERTK expressed on human dendritic cells suppressed naïve $\mathrm{CD}^{+} \mathrm{T}$ cell proliferation [156]. The anti-inflammatory effect of MERTK activation in macrophages and apoptotic cell-treated dendritic cells was mediated by inhibition of NFkB activation $[50,157,158]$ or by induction of toll-like receptor (TLR) suppressor of cytokine signaling 1 (SOCS1) and SOCS3 [158-160] (Figure 2). Further, the MERTK ligand PROS1 also promotes resolution of inflammation by macrophages and inhibits macrophage M1 polarization to reduce anti-tumor immune response [161]. More recently, MERTK blockade using anti-MERTK antibody induced a rapid local type I IFN response in tumors [162]. The type I IFNs in turn upregulated the TAM receptors through IFNAR-STAT1 signaling and the upregulated TAM system hijacked the IFNAR-STAT1 cassette to induce the cytokine and TLR suppressors SOCS1 and SOC3 [158,163-167] (Figure 3A). AXL knockout in tumor cells also promoted antigen presentation through increased MHCI expression, leading to an enhanced $\mathrm{CD}^{+} \mathrm{T}$ cell response [71]. Furthermore, treatment with the pan-TAM kinase inhibitor sitravatinib reduced tumor burden via activated innate and adaptive immune cells [168]. Additionally, treatment with sitravatinib converted immunosuppressive M2-type macrophages to immunostimulatory M1-type macrophages [168], and this effect was dependent on MERTK expression in bone marrow derived macrophages [158,168]. These findings support roles for MERTK and AXL as tolerogenic receptors that mediate immunosuppression in the tumor microenvironment [143,151,167,169].

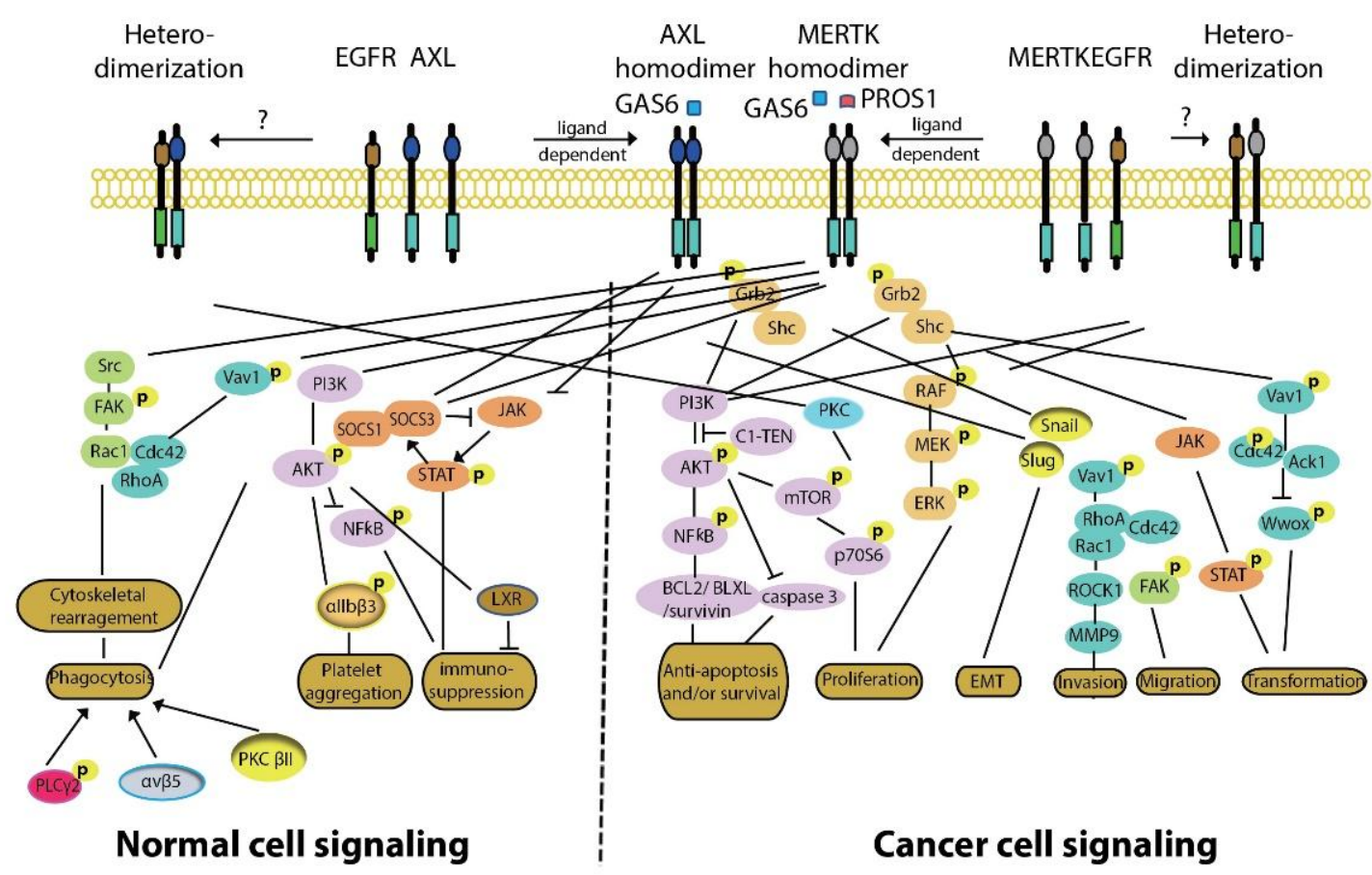

Figure 2. MERTK and AXL signaling in normal and cancer cells. MERTK and AXL play important physiological roles in phagocytosis, platelet aggregation, and immune suppression. Abnormally expressed MERTK and/AXL on NSCLC and other cancer cells are involved in tumorigenesis, including promoting tumor cell survival and proliferation and tumor cell invasion and metastasis. Besides, cross talk between AXL and EGFR, MERTK and EGFR, and AXL and MERTK have also been implicated in drug resistance in the treatment of NSCLC. 


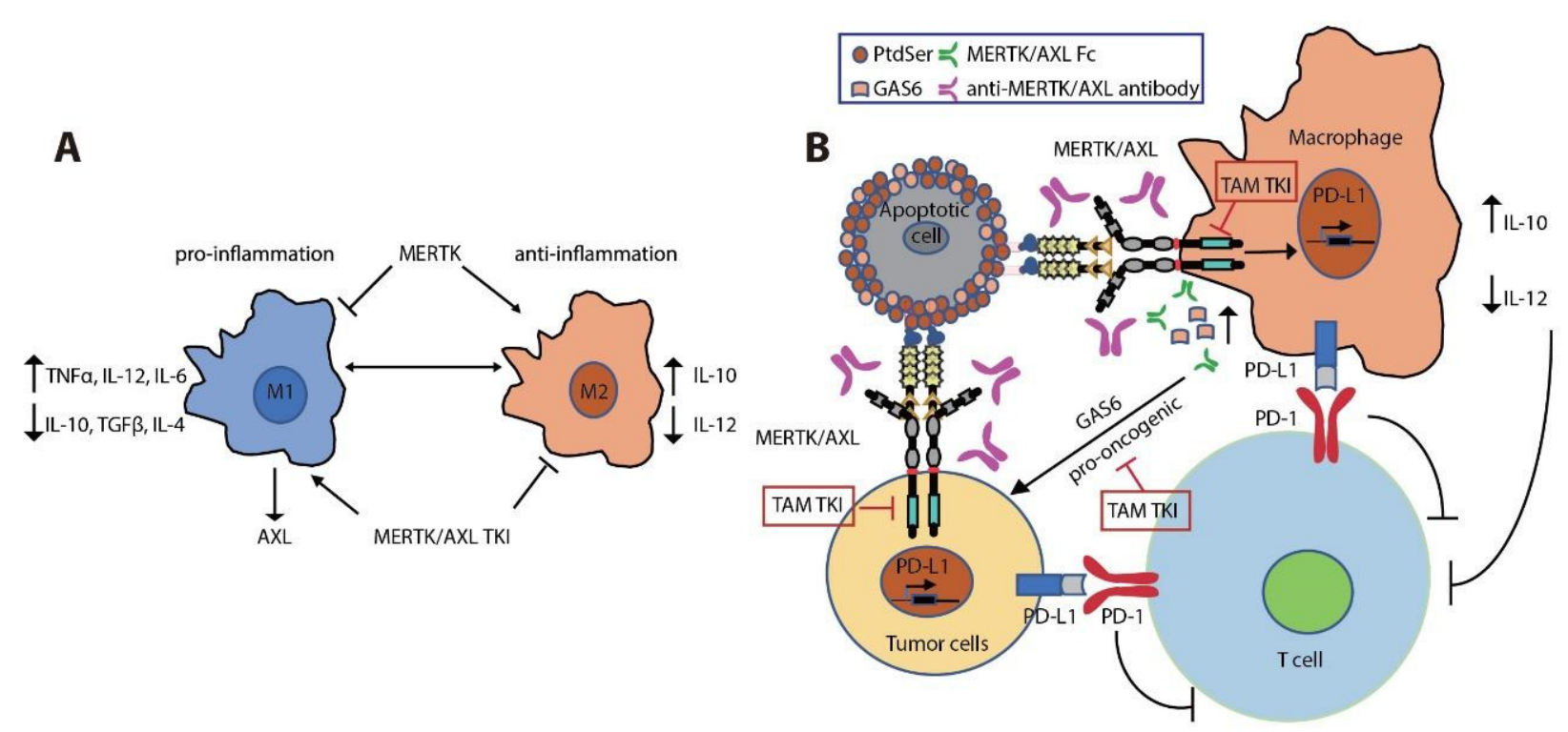

Figure 3. Immune regulatory roles of MERTK and AXL in the TME. (A) MERTK signaling favors macrophage to M2 type to generate immunosuppressive microenvironment through releasing anti-inflammatory cytokine IL-10 and decreasing the release of pro-inflammatory cytokines IL-12 and TNF $\alpha$. While expression of AXL is promoted by pro-inflammatory M1 macrophage, treatment with MERTK/AXL TKI promotes M2 to M1 macrophage development. (B) MERTK/AXL signaling favors tumor growth in cancer through two independent mechanisms. Enhanced GAS6 secretion by tumor-associated macrophages promote tumor growth through the activation of oncogenic MERTK/AXL signaling in tumor cells. Activation of MERTK in tumor-associated macrophages and in tumor cells promotes PD-L1 expression, resulting in suppression of T cell activation. Besides, the immunosuppressive cytokine environment limits $\mathrm{T}$ cell proliferation and effector functions.

Enhanced TAM receptor signaling in response to PtdSer expressed on apoptotic cells resulted in AKT-dependent PD-L1 expression on tumor cells and macrophages, and MERTK inhibition by genetic deletion or treatment with MERTK inhibitor MRX-2843 led to decreased expression of PD-L1 on tumor cells and innate immune cells [170]. In turn, T cell function was indirectly suppressed $[38,170,171]$ (Figure 3B). AXL expression was positively correlated with PD-L1 and CXC chemokine receptor 6 (CXCR6) expression in lung cancer, especially in mtEGFR-expressing NSCLC [172,173]. Similar to MERTK inhibition, treatment with AXL inhibitor R428 decreased mRNA expression of PD-L1 and CXCR6 in mtEGFRexpressing NSCLC [172]. In contrast, increased expression of AXL coincided with reduced overall survival in patients treated with PD-1 blockade [172,173]. Accordingly, high levels of AXL expression in lung cancer cells correlated with intrinsic resistance to killing by both natural killer cells and cytotoxic $\mathrm{T}$ lymphocytes and this phenotype could be reversed by treatment with the AXL inhibitor R428 [174]. MERTK plays a role in phagocytosis of apoptotic cells in macrophages, but not in dendritic cells $[43,142,175]$. In contrast, AXL has a greater role in DCs and a lesser role in apoptotic cell phagocytosis by macrophages [176]. Recently, Zhou et al. found that MERTK blockade on tumor-associated macrophages led to accumulation of dying or dead cells in the tumor, resulting in a large increase in extracellular ATP when cells became necrotic $[162,177,178]$. The increased extracellular ATP in turn opened the ATP-gated P2 $\times 7 \mathrm{R}$ channel and allowed tumor-derived extracellular cGAMP to reach the cytosol of immune cells to activate the adaptor protein stimulator of interferon genes (STING), which in turn triggered the TANK-binding kinase 1-interferon regulatory factor 3 (TBK1-IRF3)-dependent signaling process, leading to the production of type I IFNs [162,179-183]. Cyclic GAMP-AMP synthase (cGAS)-STING signaling in immune cells is a key determinant for therapeutic efficacy of immune checkpoint inhibitors [182,184]. Indeed, blockade of MERTK or AXL using a specific antibody or treatment with sitravatinib or R428 synergized with anti-PD-1 or anti-PD-L1 therapy to enhance anti-tumor immune responses [86,162,168]. 
Immunotherapies, including checkpoint inhibitors, are making an impact as monotherapy and in combination [185]. In a clinical trial in patients with advanced NSCLC without activating EGFR or ALK mutation and with PD-L1 expression on greater than $50 \%$ of tumor cells, pembrolizumab increased response rate (45\% vs. $28 \%$ ), progression-free survival (PFS, 10.3 vs. 6 months) and overall survival (30 vs. 14.2 months) relative to patients treated with chemotherapy, establishing pembrolizumab as the standard of care for these patients [186]. Further work is necessary to explore specific mechanisms of primary and adaptive resistance.

\section{Targeting TAM Kinases and EGFR in NSCLC}

Although most naïve mtEGFR-expressing NSCLC cells are initially sensitive to EGFR TKI treatment $[15,17,187,188]$, acquired resistance eventually happens [189-195] and AXL and/or GAS6 are frequently upregulated [53,58,196,197]. Other mechanisms that drive secondary resistance to EGFR TKIs are summarized in Table 1. MERTK and AXL are co-expressed with EGFR in NSCLC $[58,69,80]$, and both receptors, but especially AXL, have been studied as causative drivers of secondary EGFR TKI resistance in mtEGFRexpressing NSCLCs $[53,70,112,196]$. Forced expression of an active form of AXL, but not a kinase-impaired AXL, in erlotinib-sensitive tumor cells was sufficient to induce erlotinib resistance [53]. AXL or GAS6 knockdown [53], AXL degradation [75,198], treatment with an AXL blocking antibody [70], or treatment with the small molecule AXL inhibitors XL880 [53], MP-470 [53], SGI-7079 [112], MGCD265 [199], MGCD516 [199], DS-1205b [200], or R428 [199,201] sensitized NSCLC cells to first generation EGFR TKIs (gefitinib or erlotinib) and delayed onset of resistance relative to EGFR TKI alone [200]. Similarly, MERTK overexpression was sufficient to confer erlotinib resistance in a mtEGFR-expressing NSCLC cell line and treatment with a MERTK-selective inhibitor re-sensitized the cells to erlotinib [55]. In paired patient samples collected before and after EGFR TKI treatment, co-expression of AXL and GAS6 was increased in 5 of 35 specimens and 5 additional samples exhibited upregulation of GAS6 alone [53].

Table 1. Mechanisms of resistance to EGFR TKIs independent of TAM kinases.

\begin{tabular}{|c|c|c|c|}
\hline EGFR TKI & Mechanism of Resistance & Treatment & Reference \\
\hline \multirow{14}{*}{ Gefitinib/erlotinib } & EGFR T790M mutation & $\begin{array}{c}\text { afatinib, afatinib + rapamycin, } \\
\text { CI-387,785, dacomitinib, HKI-272, } \\
\text { CO-1686, osimertinib, WK88-1, afatinib } \\
\text { + MET inhibitor ARQ 197, PF00299804 }\end{array}$ & {$[192,195,202-208]$} \\
\hline & EGFR T854A mutation & BIBW2992 & [209] \\
\hline & EGFR exon 20 mutation & & {$[210]$} \\
\hline & EMT & MS-275 + erlotinib & {$[116]$} \\
\hline & $\begin{array}{c}\text { MET amp/hepatocyte growth factor } \\
\text { (HGF) overexpression }\end{array}$ & $\begin{array}{l}\text { PHA-665752 + gefitinib, XL880, } \\
\text { crizotinib + afatinib or WZ4002, } \\
\text { NPS-1034 + gefitinib or erlotinib }\end{array}$ & {$[73,205,211-214]$} \\
\hline & IGF-1R overexpression & AEW541 + gefitinib & {$[215]$} \\
\hline & FGFR1 overexpression/FGFR3 fusion & PD173074 + afatinib & {$[216]$} \\
\hline & $\begin{array}{l}\text { Small cell lung cancer (SCLC) } \\
\text { transformation }\end{array}$ & Standard SCLC treatments & {$[117,205]$} \\
\hline & HER2 amp/mutation & & {$[205]$} \\
\hline & EGFR T263P/G719A & afatinib & {$[217]$} \\
\hline & $\begin{array}{l}\text { NRAS mutation/BRAF } \\
\text { mutation/BRAF fusion }\end{array}$ & $\begin{array}{l}\text { MEK inhibitor AZD6244 + erlotinib or } \\
\text { BRAF inhibitor vemurafenib + erlotinib }\end{array}$ & {$[218,219]$} \\
\hline & Reduced neurofibromin & MEK inhibitor AZD6244 + erlotinib & {$[220]$} \\
\hline & CCDC6-RET fusion & & {$[219]$} \\
\hline & Glucose metabolism & 2-deoxy-D-glucose + afatinib & {$[221]$} \\
\hline
\end{tabular}


Table 1. Cont.

\begin{tabular}{|c|c|c|c|}
\hline EGFR TKI & Mechanism of Resistance & Treatment & Reference \\
\hline WZ4002 & ERK2 amp & MEK inhibitor CI-1040 + WZ4002 & [222] \\
\hline \multirow{4}{*}{ Afatinib } & $\begin{array}{l}\text { IL-6R/JAK1/STAT3 activation or } \\
\text { TGF- } \beta-\text { IL- } 6 \text { axis activation }\end{array}$ & Pyridone $6+$ afatinib & [223-225] \\
\hline & FGFR3 fusion & & [219] \\
\hline & RET fusion & & [219] \\
\hline & $A L K$ fusion & & [219] \\
\hline \multirow{14}{*}{ Osimertinib } & MET amp/HGF overexpression & & {$[27,226-229]$} \\
\hline & EGFR C797S mutation & & {$[27,29,226-231]$} \\
\hline & EGFR C724S mutation & afatinib & {$[232,233]$} \\
\hline & RET fusion & RET inhibitor BLU-667 + osimertinib & {$[27,229,234,235]$} \\
\hline & $P C B P 2-B R A F$ fusion & MEK inhibitor trametinib & [27] \\
\hline & SCLC transformation & & {$[226,229]$} \\
\hline & $\begin{array}{l}\text { FGFR1 mutation/FGFR1 } \\
\text { amp/FGFR3-TACC3 fusion }\end{array}$ & & {$[226,229]$} \\
\hline & KRAS mutation & & {$[229,230]$} \\
\hline & PIK3CA mutation/PIK3CA amp & & [226-230] \\
\hline & HER2 amp/HER2 insertion & & {$[227,228,230]$} \\
\hline & $B R A F$ mutation $/ B R A F$ fusion & & {$[219,229]$} \\
\hline & EGFR T790M loss & & {$[229,230]$} \\
\hline & $A L K$ fusion & & {$[219,234]$} \\
\hline & JAK2 mutation & & [230] \\
\hline
\end{tabular}

Osimertinib is currently the preferred treatment choice for NSCLCs with mtEGFR due to its superior efficacy compared to earlier generation EGFR TKIs [22,230,236-239]. However, osimertinib resistance inevitably occurs, and the mechanisms of resistance to osimertinib are not clear in approximately two-thirds of resistant cases $[195,197,240]$. A more detailed mechanistic understanding is needed to facilitate development of effective approaches to overcome resistance [241]. Upregulation of MERTK and AXL has been observed in osimertinib-resistant mtEGFR-expressing NSCLC cell lines, implicating these kinases as mediators of resistance $[54,80]$. In addition, both MERTK and PROS1 were upregulated in osimertinib-resistant $\mathrm{mtEGFR} \mathrm{NSCLC} \mathrm{cell} \mathrm{line} \mathrm{derivatives} \mathrm{and} \mathrm{in} \mathrm{mt} E G F R$ NSCLC xenograft tumors treated with osimertinib. Moreover, treatment with MERTK kinase inhibitor MRX-2843 [67,242] re-sensitized resistant cells to osimertinib in cell-based assays and provided durable tumor regression in a mtEGFR NSCLC xenograft model, even after treatment ended [80]. NSCLCs expressing mtEGFR and high levels of AXL were more tolerant to osimertinib treatment than tumors expressing low levels of AXL $[54,241]$. Treatment with an AXL degrader [198] or an AXL inhibitor DS-1205b [200], ONO-7475 [82], or NPS-1034 [54] reversed osimertinib resistance. Additionally, increased IGF-1R signaling was observed in AXL-low mtEGFR-expressing NSCLC tumor cells treated with osimertinib and knockout of IGF-1R sensitized AXL-low NSCLC cells to osimertinib, suggesting that IGF-1R drives cell survival in the presence of osimertinib [241]. Indeed, transient IGF-1R inhibition combined with continuous osimertinib eradicated tumors and provided durable tumor growth inhibition even after cessation of osimertinib [241,243].

AXL overexpression and activation also conferred resistance to EGFR antibody cetuximab in NSCLC models both in vitro and in vivo and AXL knockdown decreased EGFR phosphorylation in a cetuximab-resistant NSCLC cell line derivative, but not in parental cells [72]. EGFR knockdown led to a loss of total AXL protein and mRNA expression in both 
parental and cetuximab resistant cells, indicating additional levels of interplay. Treatment with an anti-AXL monoclonal antibody reduced both AXL and total EGFR, while treatment with AXL inhibitor R428 led to a loss of EGFR phosphorylation in cetuximab-resistant cells, but not in parental cells. As a result, cetuximab-resistant NSCLC cells were sensitive to anti-AXL antibody or R428 treatment. Similarly, MERTK and EGFR are frequently co-expressed in wtEGFR-expressing NSCLC cell lines [69].

Nearly $90 \%$ of EGFR mutations found in NSCLC tumors are due to deletions in exon19 or a point mutation in exon21 (L858R) [244]. In patients with NSCLCs that express low levels of $A X L$, median PFS was significantly longer in patients with EGFR exon 19 deletion (28.8 months) than in patients with NSCLCs harboring an EGFR L858R mutation (9.1 months) and patients with wild-type EGFR (11 months) $(p<0.0001)$ [245]. In patients with NSCLCs that express high levels of $A X L$, there was no significant difference in PFS time between the subtypes of mtEGFR $(p>0.05)$. Consistent with these findings, high levels of AXL correlated with poor response to initial EGFR TKIs in patients with $\mathrm{mtEGFR}$ NSCLC $[54,65]$. A subpopulation of AXL-positive cancer cells were found in erlotinib-naïve tumors [60], providing rationale to treat mtEGFR-expressing NSCLCs with AXL and EGFR TKIs combined in order to delay or prevent resistance.

\section{MERTK and AXL Inhibitors for Potential Use in NSCLC}

Several RTK inhibitors that target lung cancer abnormalities, such as EGFR mutation, $A L K$ fusion, MET amplification, and KRAS mutation, are either in clinical use or currently in clinical trials [237,246-248]. Targeting MERTK and AXL may have dual benefits: (1) directly targeting and killing cancer cells and (2) indirectly impacting tumor growth through modulation of the tumor microenvironment $[83,249]$. Current translatable inhibitors blocking TAM receptors include biologic agents and small molecule inhibitors (Tables 2 and 3).

Table 2. Summary of biological agents for MERTK/AXL.

\begin{tabular}{|c|c|c|c|c|}
\hline Compound & Known Targets & Phase & AXL IC 50 & Reference \\
\hline \multicolumn{5}{|l|}{ Monoclonal antibody } \\
\hline YW327.6S2 & AXL-specific & Preclinical & $340 \mathrm{ng} / \mathrm{mL}$ & [70] \\
\hline 12A11 & AXL-specific & Preclinical & $\sim 100 \mathrm{ng} / \mathrm{mL}$ & [64] \\
\hline MA b173 & AXL-specific & Preclinical & Unk & [250] \\
\hline D9 and E8 & AXL-specific & Preclinical & Unk & [251] \\
\hline AXL polyclonal antibody & AXL-specific & Preclinical & Unk & [252] \\
\hline Mer590 & MERTK-specific & Preclinical & $6.25 \mathrm{ng} / \mathrm{mL}$ & {$[66,136]$} \\
\hline \multicolumn{5}{|l|}{ Recombinant Protein } \\
\hline AXL-FC & AXL, MERTK, TYRO3 & preclinical & Unk & {$[37,253]$} \\
\hline MERTK-Fc & AXL, MERTK, TYRO3 & Preclinical & Unk & [37] \\
\hline \multicolumn{5}{|l|}{ Decoy receptor } \\
\hline AXL "decoy receptor" & GAS6 & Preclinical & $0.5 \mathrm{mg} / \mathrm{kg}$ & [254] \\
\hline Aptamer GL21.T & AXL-specific & Preclinical & $13 \mathrm{nM}(\mathrm{Kd})$ & [255] \\
\hline $\begin{array}{l}\text { Antibody-drug conjugate } \\
\text { BA3011/CAB-AXL-ADC }\end{array}$ & AXL & $\mathrm{I} / \mathrm{II}$ & Unk & [256] \\
\hline $\begin{array}{l}\text { Antibody-drug conjugate } \\
\text { HuMax-AXL-ADC }\end{array}$ & AXL & $\mathrm{I} / \mathrm{II}$ & $\begin{array}{l}0.02-2 \mu \mathrm{g} / \mathrm{mL} \\
\quad \text { (in vitro) }\end{array}$ & [92] \\
\hline $\begin{array}{l}\text { Antibody-drug conjugate } \\
\text { CAB-AXL-ADC }\end{array}$ & AXL & $\mathrm{I} / \mathrm{II}$ & Unk & [257] \\
\hline $\begin{array}{c}\text { AXL-FC } \\
\text { AVB-S6-500 }\end{array}$ & GAS6 & I/II/III & Unk & [258] \\
\hline $\begin{array}{c}\text { CAR-T } \\
\text { CCT301-38 }\end{array}$ & AXL & $\mathrm{I} / \mathrm{II}$ & Unk & [259] \\
\hline
\end{tabular}


Table 3. Summary of small molecule MERTK/AXL kinase inhibitors in clinical trials.

\begin{tabular}{|c|c|c|c|c|c|c|}
\hline Compound & Known Targets & Phase & AXL IC 50 & MERTK IC 50 & NCT Number & References \\
\hline MRX-2843 & MERTK, FLT3 & $\mathrm{I} / \mathrm{Ib}$ & $15 \mathrm{nM}$ (in vitro) & $\begin{array}{l}1.3 \mathrm{nM} \\
\text { (in vitro) }\end{array}$ & $\begin{array}{l}\text { NCT03510104 } \\
\text { NCT04762199 }\end{array}$ & {$[67,69,242]$} \\
\hline DS-1205c & & I & $\begin{array}{c}1.3 \mathrm{nM} \\
\text { (in vitro) }\end{array}$ & $63 \mathrm{nM}$ (in vitro) & $\begin{array}{l}\text { NCT03255083 } \\
\text { NCT03599518 }\end{array}$ & [200] \\
\hline S49076 & $\begin{array}{c}\text { AXL, MET, EGFR, } \\
\text { ISRC, } \\
\text { FGFR } 1 / 2 / 3\end{array}$ & $\mathrm{I} / \mathrm{II}$ & 7 nM (in vitro) & 2 nM (in vitro) & ISRCTN00759419 & [260] \\
\hline $\begin{array}{c}\text { ASLAN002 } \\
\text { (BMS-777607) }\end{array}$ & $\begin{array}{l}\text { AXL, MERTK, } \\
\text { and MET }\end{array}$ & $\mathrm{I} / \mathrm{II}$ & $\begin{array}{c}1.1 \mathrm{nM} \\
\text { (in vitro) }\end{array}$ & $16 \mathrm{nM}$ (in vitro) & $\begin{array}{l}\text { NCT01721148 } \\
\text { NCT00605618 }\end{array}$ & [261] \\
\hline LY2801653 & $\begin{array}{l}\text { AXL, MET, } \\
\text { MST1R }\end{array}$ & I & $2 \mathrm{nM}$ (in vitro) & $10 \mathrm{nM}$ (in vitro) & NCT01285037 & [262] \\
\hline INCB081776 & AXL, MERTK & I & $\begin{array}{l}0.61 \mathrm{nM} \\
\text { (in vitro) }\end{array}$ & $\begin{array}{l}3.17 \mathrm{nM} \\
\text { (in vitro) }\end{array}$ & NCT03522142 & [83] \\
\hline $\begin{array}{l}\text { Sitravatinib } \\
\text { (MGCD516) }\end{array}$ & $\begin{array}{l}\text { AXL, MET, RET, } \\
\text { TRK, DDR2, KDR, } \\
\text { PDGFRA, Kit }\end{array}$ & I & $\begin{array}{l}1.5 \mathrm{nM} \\
\text { (in vitro) }\end{array}$ & $2 \mathrm{nM}$ (in vitro) & NCT02219711 & [263] \\
\hline SU14813 & $\begin{array}{l}\text { FLT3, VEGFR, } \\
\text { PDGFR, Kit }\end{array}$ & I & $84 \mathrm{nM}$ (in vitro) & $66 \mathrm{nM}$ (in vitro) & NCT00982267 & [264] \\
\hline RXDX106 & $\begin{array}{l}\text { AXL, MERTK, } \\
\text { TYRO3, MET }\end{array}$ & I & $\begin{array}{l}0.69 \mathrm{nM} \\
\text { (in vitro) }\end{array}$ & $\begin{array}{l}1.89 \mathrm{nM} \\
\text { (in vitro) }\end{array}$ & NCT03454243 & [249] \\
\hline $\begin{array}{l}\text { Bosutinib } \\
\text { (SKI-606/PF- } \\
\text { 5208763) }\end{array}$ & $\begin{array}{l}\text { AXL, Src, AbI, } \\
\text { TGFB, BMP }\end{array}$ & $\mathrm{I} / \mathrm{II}$ & $\begin{array}{l}0.56 \mu \mathrm{M} \\
\text { (in vitro) }\end{array}$ & Unk & $\begin{array}{l}\text { NCT00195260 } \\
\text { NCT00319254 }\end{array}$ & [265] \\
\hline $\begin{array}{l}\text { Amuvatinib } \\
\text { (MP470) }\end{array}$ & $\begin{array}{l}\text { AXL, c-KIT, } \\
\text { PDGFR, FLT3, } \\
\text { RAD51, RET }\end{array}$ & $\mathrm{I} / \mathrm{Ib} / \mathrm{II}$ & $<1 \mu \mathrm{M}$ (in cells) & Unk & $\begin{array}{l}\text { NCT00894894 } \\
\text { NCT00881166 } \\
\text { NCT01357395 }\end{array}$ & [266] \\
\hline $\begin{array}{l}\text { Gilteritinib } \\
\text { (ASP2215) }\end{array}$ & AXL, FLT3 & $\mathrm{I} / \mathrm{II} / \mathrm{III}$ & $<1 \mathrm{nM}$ (in vitro) & Unk & $\begin{array}{l}\text { NCT02014558 } \\
\text { NCT02421939 } \\
\text { NCT02752035 } \\
\text { NCT02927262 } \\
\text { NCT02997202 } \\
\text { NCT03182244 } \\
\text { NCT02561455 } \\
\text { NCT02456883 }\end{array}$ & {$[253,267]$} \\
\hline $\begin{array}{l}\text { Glesatinib } \\
\text { (MGCD265) }\end{array}$ & $\begin{array}{l}\text { AXL, MET, } \\
\text { VEGFR }\end{array}$ & $\mathrm{I} / \mathrm{II}$ & Unk & Unk & $\begin{array}{l}\text { NCT00697632 } \\
\text { NCT00975767 }\end{array}$ & [268] \\
\hline Ningetinib & $\begin{array}{l}\text { VEGFR2, MET, } \\
\text { AXL, MERTK, } \\
\text { FLT3, RON }\end{array}$ & $\mathrm{I} / \mathrm{II}$ & $<1 \mathrm{nM}$ (in vitro) & Unk & $\begin{array}{l}\text { NCT03758287 } \\
\text { NCT04577703 }\end{array}$ & [269] \\
\hline $\begin{array}{l}\text { Merestinib } \\
\text { (LY2801653) }\end{array}$ & $\begin{array}{c}\text { MET, RON, FLT3, } \\
\text { AXL }\end{array}$ & $\mathrm{I} / \mathrm{II}$ & 2 nM (in vitro) & $10 \mathrm{nM}$ (in vitro) & $\begin{array}{l}\text { NCT01285037 } \\
\text { NCT03027284 } \\
\text { NCT02711553 }\end{array}$ & [262] \\
\hline $\begin{array}{l}\text { BGB324 } \\
\text { (R428) }\end{array}$ & AXL & $\mathrm{I} / \mathrm{II}$ & $\begin{array}{c}14 \mathrm{nM} \text { (in vitro) } \\
<30 \mathrm{nM} \\
\text { (in cells) }\end{array}$ & $\begin{array}{l}224 \mathrm{nM} \\
\text { (in vitro) }\end{array}$ & $\begin{array}{l}\text { NCT024 } 24617 \\
\text { NCT02488408 } \\
\text { NCT02872259 } \\
\text { NCT02922777 } \\
\text { NCT03184558 } \\
\text { NCT03184571 } \\
\text { NCT03649321 } \\
\text { NCT03654833 }\end{array}$ & [270] \\
\hline
\end{tabular}


Table 3. Cont

\begin{tabular}{|c|c|c|c|c|c|c|}
\hline Compound & Known Targets & Phase & AXL IC 50 & MERTK IC I0 $_{2}$ & NCT Number & References \\
\hline $\begin{array}{c}\text { Crizotinib } \\
(\text { PF-02341066) }\end{array}$ & $\begin{array}{l}\text { ALK, MET, ROS1, } \\
\text { AXL }\end{array}$ & $\mathrm{Ib} / \mathrm{II}$ & $0.3 \mu \mathrm{M}$ & Unk & $\begin{array}{l}\text { NCT02034981 } \\
\text { NCT02511184 }\end{array}$ & [24] \\
\hline TP-0903 & AXL & $\mathrm{I} / \mathrm{II}$ & $\begin{array}{c}27 \mathrm{nM} \text { (in vitro) } \\
222 \mathrm{nM} \text { (in } \\
\text { cells) }\end{array}$ & Unk & $\begin{array}{l}\text { NCT02729298 } \\
\text { NCT03572634 }\end{array}$ & [113] \\
\hline ONO-7475 & AXL, MERTK & $\mathrm{I} / \mathrm{II}$ & $\begin{array}{l}0.7 \mathrm{nM} \\
\text { (in vitro) }\end{array}$ & $1 \mathrm{nM}$ (in vitro) & $\begin{array}{l}\text { NCT03176277 } \\
\text { NCT03730337 }\end{array}$ & [82] \\
\hline SGI-7079 & AXL & II & $58 \mathrm{nM}$ (in vitro) & Unk & NCT00409968 & {$[112,271]$} \\
\hline $\begin{array}{l}\text { Sunitinib } \\
\text { (SU11248) }\end{array}$ & $\begin{array}{c}\text { KIT, FLT3, } \\
\text { PDGFR, VEGFR2, } \\
\text { AXL }\end{array}$ & II & 9 nM (in vitro) & Unk & $\begin{array}{l}\text { NCT01499121 } \\
\text { NCT01034878 } \\
\text { NCT00864721 }\end{array}$ & [272] \\
\hline $\begin{array}{c}\text { Foretinib } \\
\text { (GSK1363089/XL880) }\end{array}$ & $\begin{array}{c}\text { MET, AXL, } \\
\text { VEGFR2, RON, } \\
\text { Tie-2 }\end{array}$ & II & $11 \mathrm{nM}$ (in vitro) & Unk & NCT01068587 & [273] \\
\hline $\begin{array}{l}\text { Cabozantinib } \\
\quad(\text { XL184) }\end{array}$ & $\begin{array}{c}\text { AXL, MET, } \\
\text { VEGFR2, RET, } \\
\text { Kit, Flt-1/3/4, } \\
\text { Tie2 }\end{array}$ & II/III & $\begin{array}{l}7 \mathrm{nM} \text { (in vitro) } \\
42 \mathrm{nM} \text { (in cells) }\end{array}$ & Unk & $\begin{array}{l}\text { NCT01639508 } \\
\text { NCT01708954 } \\
\text { NCT01866410 }\end{array}$ & [274] \\
\hline
\end{tabular}

\subsection{Biological Agents}

Antibodies are likely to be the most specific inhibitors of MERTK or AXL with reduced off-target effects (Figure 3B). Treatment with inhibitory anti-AXL monoclonal antibodies YM327.6S2 or 12A11 inhibited tumor growth in a NSCLC xenograft model [64]. The AXL antibody hMAb173 induced apoptosis of renal carcinoma cells and inhibited tumor growth by $78 \%$ in vivo [250]. Two additional anti-AXL mAbs (D9 and E8) decreased AXL expression by promoting AXL internalization, resulting in inhibition of proliferation and migration in vitro and reduced tumor growth in murine models [251]. Similarly, the anti-MERTK monoclonal antibody Mer590 reduced surface MERTK protein levels by $87 \%$ and increased chemosensitivity and reduced colony formation in NSCLC cell lines [66]. Antibodies are likely to be the most specific inhibitors of MERTK or AXL with reduced off-target effects (Figure 3B). Treatment with inhibitory anti-AXL monoclonal antibodies YM327.6S2 or 12A11 inhibited tumor growth in a NSCLC xenograft model [64]. The AXL antibody hMAb173 induced apoptosis of renal carcinoma cells and inhibited tumor growth by $78 \%$ in vivo [250]. Two additional anti-AXL mAbs (D9 and E8) decreased AXL expression by promoting AXL internalization, resulting in inhibition of proliferation and migration in vitro and reduced tumor growth in murine models [251]. Similarly, the antiMERTK monoclonal antibody Mer590 reduced surface MERTK protein levels by $87 \%$ and increased chemosensitivity and reduced colony formation in NSCLC cell lines [66].

In addition to anti-TAM specific antibodies, ligand sinks have been developed to block activation of the TAM kinases. GL21.T, a selective RNA-based aptamer, bound to the ectodomain regions of AXL $(\mathrm{Kd}=12 \mathrm{nM})$ and reduced catalytic activity and AXLdependent signaling, inhibited cellular migration and invasion, and reduced NSCLC tumor volume by $68.2 \%$ in vivo [255,275]. Extracellular domains of MERTK and AXL fused to the Fc domain of immunoglobulin G1 can also titrate GAS6 and thereby block GAS6-dependent signaling through the TAM kinases, resulting in decreased tumor metastasis [104] (Figure 3B). Several engineered AXL decoy receptors with 80-fold higher affinity for GAS6 compared to the wild-type AXL receptor significantly reduced tumor burden and metastasis in vivo $[254,276,277]$. Antibody-drug conjugates, AXL-Fc fusion proteins, and CAR-T therapies directed against the TAM receptors are in clinical trials (Table 2). 


\subsection{Small Molecule Inhibitors}

Several small molecules targeting MERTK and/or AXL are in preclinical development. Both AXL and the structurally related kinase MET are frequent mediators of resistance in NSCLC and targeting both may be particularly effective to prevent resistance $[212,278,279]$. MET and AXL share similar ATP binding sites so small molecule inhibitors targeting MET often inhibit AXL as well [280]. Treatment with NPS-1034, a dual AXL (IC50 =10.3 nM) and MET $\left(\mathrm{IC}_{50}=48 \mathrm{nM}\right)$ kinase inhibitor, overcame resistance to EGFR TKIs associated with MET and/or AXL abnormalities [73]. Treatment with LDC1267, a potent and selective TAM kinase inhibitor, enhanced anti-metastatic NK cell activity in vivo [281]. UNC2025 and MRX-2843 are structurally related and orally available MERTK-selective inhibitors suitable for clinical application $[67,242]$. Both compounds induced apoptosis and decreased colony formation in MERTK-dependent NSCLC cell lines and reduced tumor growth in murine models $[68,69]$. MRX-2843 also enhanced inhibition of downstream oncogenic signaling in combination with third-generation EGFR TKIs, including osimertinib, resulting in more robust anti-tumor activity both in vitro and in vivo [69,80]. Based on these findings, MRX-2843 is currently in phase I/Ib clinical trials, including an ongoing trial testing MRX-2843 and osimertinib for treatment of advanced mtEGFR-expressing NSCLC (Clinicaltrials.gov, NCT04762199). Translational TAM kinase inhibitors also have demonstrated immune-mediated therapeutic activity in preclinical models. Treatment with a pan-TAM TKI RXDX-106 increased tumor-infiltrating leukocytes, M1-polarized intratumoral macrophages, and natural killer cell activation and decreased tumor growth [249]. UNC2025 decreased anti-inflammatory M2 macrophages in glioblastoma [282]. MRX-2843 decreased PD-L1 and PD-L2 expression on CD11b ${ }^{+}$monocytes/macrophages and indirectly decreased PD-1 expression on T cells, leading to increased $\mathrm{T}$ cell activation in the tumor microenvironment [170].

Because the TAM kinases are closely related, it is likely that many of the inhibitors that were not specifically designed for selectivity are not selective amongst the TAM kinases. This lack of specificity may be an advantage for some applications. The TAM kinases have overlapping functions and they may provide bypass signaling to compensate for selective inhibition of other family members. For instance, MERTK is upregulated in NSCLC cell lines in response to AXL inhibition and promotes resistance to AXL inhibitors [78]. Moreover, inhibition of MERTK sensitized NSCLC cells to AXL inhibition. Thus, in at least some cases agents that target both AXL and MERTK may provide better tumor growth control than more selective compounds.

\subsection{Potential on-Target Toxicities Associated with MERTK and/or AXL Inhibition}

Long-term inhibition of MERTK and/or AXL may cause adverse effects correlated with their important physiologic roles. Retinal pigment epithelial (RPE) cells may fail to phagocytose shed outer segments [283], leading to impaired vision. Additionally, defects in phagocytosis and defects in downregulation of the immune response may cause increased production of self-reactive antibodies and development of autoimmunity $[43,48,176]$. MERTK and AXL are also expressed on platelets and play roles in clot stabilization $[49,284,285]$. TAM kinase inhibition may therefore lead to reduced clot stability, although bleeding times are not changed in mice with Mertk knock-out or treated with UNC2025 [286]. White and red blood cell counts are decreased in mice treated with high doses of UNC2025 or MRX-2843 [170,287]. These potential toxicities will need to be carefully monitored in ongoing clinical trials.

\section{Conclusions}

MERTK and AXL mediate multiple oncogenic phenotypes in lung cancer, including tumor cell growth, survival, metastasis, invasion, and drug resistance, and are potential targets for lung cancer treatment. Early phase clinical trials of MERTK and AXL inhibitors are underway, and their results will inform future trials. Biomarker-driven clinical trials of selective MERTK and/or AXL inhibitors with real-time monitoring of MERTK and/or 
AXL activity will better define the true potential of targeting MERTK and/or AXL in the clinic to improve patient outcomes.

Author Contributions: Conceptualization, D.Y., D.D. and D.K.G.; software, D.Y.; validation, D.Y., H.S.E., D.D. and D.K.G.; investigation, D.Y.; resources, D.Y.; data curation, D.Y.; writing—original draft preparation, D.Y.; writing - review and editing, D.Y., H.S.E., D.D. and D.K.G.; visualization, D.Y.; supervision, D.D. and D.K.G.; project administration, D.Y.; funding acquisition, D.K.G. All authors have read and agreed to the published version of the manuscript.

Funding: Research reported in this publication was supported by the National Cancer Institute of the National Institutes of Health (Emory Lung Cancer Spore, Award Number P50CA217691). The content is solely the responsibility of the authors and does not necessarily represent the official views of the National Institutes of Health.

Conflicts of Interest: D.K.G. and H.S.E. are founders and serve on the Board of Directors of Meryx, Inc. H.S.E., D.K.G. and D.D. are equity holders in Meryx, Inc. The company's key clinical candidate MRX-2843 is discussed in this review. D.Y., H.S.E., D.D. and D.K.G. are inventors on a patent describing the use of MRX-2843 in combination with osimertinib.

\section{References}

1. Zappa, C.; Mousa, S.A. Non-small cell lung cancer: Current treatment and future advances. Transl. Lung Cancer Res. 2016, 5, 288-300. [CrossRef]

2. Duma, N.; Santana-Davila, R.; Molina, J.R. Non-Small Cell Lung Cancer: Epidemiology, Screening, Diagnosis, and Treatment. Mayo Clin. Proc. 2019, 94, 1623-1640. [CrossRef]

3. Travis, W.D.; Brambilla, E.; Nicholson, A.G.; Yatabe, Y.; Austin, J.H.M.; Beasley, M.B.; Chirieac, L.R.; Dacic, S.; Duhig, E.; Flieder, D.B.; et al. The 2015 World Health Organization Classification of Lung Tumors: Impact of Genetic, Clinical and Radiologic Advances Since the 2004 Classification. J. Thorac. Oncol. 2015, 10, 1243-1260. [CrossRef]

4. Travis, W.D.; Brambilla, E.; Burke, A.P.; Marx, A.; Nicholson, A.G. Introduction to the 2015 World Health Organization Classification of Tumors of the Lung, Pleura, Thymus, and Heart. J. Thorac. Oncol. 2015, 10, 1240-1242. [CrossRef]

5. Datta, D.; Lahiri, B. Preoperative evaluation of patients undergoing lung resection surgery. Chest 2003, 123, 2096-2103. [CrossRef]

6. Group NM-aC; Arriagada, R.; Auperin, A.; Burdett, S.; Higgins, J.P.; Johnson, D.H.; Le Chevalier, T.; Le Pechoux, C.; Parmar, M.K.; Pignon, J.P.; et al. Adjuvant chemotherapy, with or without postoperative radiotherapy, in operable non-small-cell lung cancer: Two meta-analyses of individual patient data. Lancet 2010, 375, 1267-1277. [CrossRef] [PubMed]

7. Labbe, C.; Anderson, M.; Simard, S.; Tremblay, L.; Laberge, F.; Vaillancourt, R.; Lacasse, Y. Wait times for diagnosis and treatment of lung cancer: A single-centre experience. Curr. Oncol. 2017, 24, 367-373. [CrossRef] [PubMed]

8. Pignon, J.P.; Tribodet, H.; Scagliotti, G.V.; Douillard, J.Y.; Shepherd, F.A.; Stephens, R.J.; Dunant, A.; Torri, V.; Rosell, R.; Seymour, L.; et al. Lung adjuvant cisplatin evaluation: A pooled analysis by the LACE Collaborative Group. J. Clin. Oncol. 2008, 26, 3552-3559. [CrossRef] [PubMed]

9. Murphy, D.J.; Blyth, K.G. Predicting lung cancer recurrence from circulating tumour DNA. Commentary on 'Phylogenetic ctDNA analysis depicts early-stage lung cancer evolution'. Cell Death Differ. 2017, 24, 1473-1474. [CrossRef]

10. Siegel, R.L.; Miller, K.D.; Fuchs, H.E.; Jemal, A. Cancer Statistics, 2021. CA Cancer J. Clin. 2021, 71, 7-33. [CrossRef]

11. Kocher, F.; Hilbe, W.; Seeber, A.; Pircher, A.; Schmid, T.; Greil, R.; Auberger, J.; Nevinny-Stickel, M.; Sterlacci, W.; Tzankov, A.; et al. Longitudinal analysis of 2293 NSCLC patients: A comprehensive study from the TYROL registry. Lung Cancer 2015, 87, 193-200. [CrossRef] [PubMed]

12. Group, N.M.-A.C. Chemotherapy in addition to supportive care improves survival in advanced non-small-cell lung cancer: A systematic review and meta-analysis of individual patient data from 16 randomized controlled trials. J. Clin. Oncol. 2008, 26, 4617-4625. [CrossRef]

13. Carney, D.N. Lung cancer-time to move on from chemotherapy. N. Engl. J. Med. 2002, 346, 126-128. [CrossRef] [PubMed]

14. Goldstraw, P.; Chansky, K.; Crowley, J.; Rami-Porta, R.; Asamura, H.; Eberhardt, W.E.; Nicholson, A.G.; Groome, P.; Mitchell, A.; Bolejack, V.; et al. The IASLC Lung Cancer Staging Project: Proposals for Revision of the TNM Stage Groupings in the Forthcoming (Eighth) Edition of the TNM Classification for Lung Cancer. J. Thorac. Oncol. 2016, 11, 39-51. [CrossRef]

15. Paez, J.G.; Janne, P.A.; Lee, J.C.; Tracy, S.; Greulich, H.; Gabriel, S.; Herman, P.; Kaye, FJ.; Lindeman, N.; Boggon, T.J.; et al. EGFR mutations in lung cancer: Correlation with clinical response to gefitinib therapy. Science 2004, 304, 1497-1500. [CrossRef]

16. Mendelsohn, J.; Baselga, J. The EGF receptor family as targets for cancer therapy. Oncogene 2000, 19, 6550-6565. [CrossRef] [PubMed]

17. Lynch, T.J.; Bell, D.W.; Sordella, R.; Gurubhagavatula, S.; Okimoto, R.A.; Brannigan, B.W.; Harris, P.L.; Haserlat, S.M.; Supko, J.G.; Haluska, F.G.; et al. Activating mutations in the epidermal growth factor receptor underlying responsiveness of non-small-cell lung cancer to gefitinib. N. Engl. J. Med. 2004, 350, 2129-2139. [CrossRef]

18. Sordella, R.; Bell, D.W.; Haber, D.A.; Settleman, J. Gefitinib-sensitizing EGFR mutations in lung cancer activate anti-apoptotic pathways. Science 2004, 305, 1163-1167. [CrossRef] 
19. Soda, M.; Choi, Y.L.; Enomoto, M.; Takada, S.; Yamashita, Y.; Ishikawa, S.; Fujiwara, S.; Watanabe, H.; Kurashina, K.; Hatanaka, H.; et al. Identification of the transforming EML4-ALK fusion gene in non-small-cell lung cancer. Nature 2007, 448, 561-566. [CrossRef]

20. Rikova, K.; Guo, A.; Zeng, Q.; Possemato, A.; Yu, J.; Haack, H.; Nardone, J.; Lee, K.; Reeves, C.; Li, Y.; et al. Global survey of phosphotyrosine signaling identifies oncogenic kinases in lung cancer. Cell 2007, 131, 1190-1203. [CrossRef]

21. Kwak, E.L.; Bang, Y.J.; Camidge, D.R.; Shaw, A.T.; Solomon, B.; Maki, R.G.; Ou, S.H.; Dezube, B.J.; Janne, P.A.; Costa, D.B.; et al Anaplastic lymphoma kinase inhibition in non-small-cell lung cancer. N. Engl. J. Med. 2010, 363, 1693-1703. [CrossRef] [PubMed]

22. Rosell, R.; Carcereny, E.; Gervais, R.; Vergnenegre, A.; Massuti, B.; Felip, E.; Palmero, R.; Garcia-Gomez, R.; Pallares, C.; Sanchez, J.M.; et al. Erlotinib versus standard chemotherapy as first-line treatment for European patients with advanced EGFR mutationpositive non-small-cell lung cancer (EURTAC): A multicentre, open-label, randomised phase 3 trial. Lancet Oncol. 2012, 13, 239-246. [CrossRef]

23. Sequist, L.V.; Yang, J.C.; Yamamoto, N.; O’Byrne, K.; Hirsh, V.; Mok, T.; Geater, S.L.; Orlov, S.; Tsai, C.M.; Boyer, M.; et al. Phase III study of afatinib or cisplatin plus pemetrexed in patients with metastatic lung adenocarcinoma with EGFR mutations. J. Clin. Oncol. 2013, 31, 3327-3334. [CrossRef]

24. Shaw, A.T.; Kim, D.W.; Nakagawa, K.; Seto, T.; Crino, L.; Ahn, M.J.; De Pas, T.; Besse, B.; Solomon, B.J.; Blackhall, F.; et al. Crizotinib versus chemotherapy in advanced ALK-positive lung cancer. N. Engl. J. Med. 2013, 368, 2385-2394. [CrossRef] [PubMed]

25. Alamgeer, M.; Ganju, V.; Watkins, D.N. Novel therapeutic targets in non-small cell lung cancer. Curr. Opin. Pharmacol. 2013, 13, 394-401. [CrossRef]

26. Gainor, J.F.; Dardaei, L.; Yoda, S.; Friboulet, L.; Leshchiner, I.; Katayama, R.; Dagogo-Jack, I.; Gadgeel, S.; Schultz, K.; Singh, M.; et al. Molecular Mechanisms of Resistance to First- and Second-Generation ALK Inhibitors in ALK-Rearranged Lung Cancer. Cancer Discov. 2016, 6, 1118-1133. [CrossRef] [PubMed]

27. Piotrowska, Z.; Isozaki, H.; Lennerz, J.K.; Gainor, J.F.; Lennes, I.T.; Zhu, V.W.; Marcoux, N.; Banwait, M.K.; Digumarthy, S.R.; Su, W.; et al. Landscape of Acquired Resistance to Osimertinib in EGFR-Mutant NSCLC and Clinical Validation of Combined EGFR and RET Inhibition with Osimertinib and BLU-667 for Acquired RET Fusion. Cancer Discov. 2018, 8, 1529-1539. [CrossRef]

28. Katayama, R.; Shaw, A.T.; Khan, T.M.; Mino-Kenudson, M.; Solomon, B.J.; Halmos, B.; Jessop, N.A.; Wain, J.C.; Yeo, A.T.; Benes, C.; et al. Mechanisms of acquired crizotinib resistance in ALK-rearranged lung Cancers. Sci. Transl. Med. 2012, 4, 120 ra17. [CrossRef]

29. Thress, K.S.; Paweletz, C.P.; Felip, E.; Cho, B.C.; Stetson, D.; Dougherty, B.; Lai, Z.; Markovets, A.; Vivancos, A.; Kuang, Y.; et al. Acquired EGFR C797S mutation mediates resistance to AZD9291 in non-small cell lung cancer harboring EGFR T790M. Nat. Med. 2015, 21, 560-562. [CrossRef]

30. Sequist, L.V.; Soria, J.C.; Goldman, J.W.; Wakelee, H.A.; Gadgeel, S.M.; Varga, A.; Papadimitrakopoulou, V.; Solomon, B.J.; Oxnard, G.R.; Dziadziuszko, R.; et al. Rociletinib in EGFR-mutated non-small-cell lung cancer. N. Engl. J. Med. 2015, 372, 1700-1709. [CrossRef]

31. O’Bryan, J.P.; Frye, R.A.; Cogswell, P.C.; Neubauer, A.; Kitch, B.; Prokop, C.; Espinosa, R., 3rd; Le Beau, M.M.; Earp, H.S.; Liu, E.T. Axl, a transforming gene isolated from primary human myeloid leukemia cells, encodes a novel receptor tyrosine kinase. Mol. Cell. Biol. 1991, 11, 5016-5031. [PubMed]

32. Graham, D.K.; Dawson, T.L.; Mullaney, D.L.; Snodgrass, H.R.; Earp, H.S. Cloning and mRNA expression analysis of a novel human protooncogene, c-mer. Cell Growth Differ. 1994, 5, 647-657. [PubMed]

33. Caberoy, N.B.; Zhou, Y.; Li, W. Tubby and tubby-like protein 1 are new MerTK ligands for phagocytosis. EMBO J. 2010, 29, 3898-3910. [CrossRef] [PubMed]

34. Caberoy, N.B.; Alvarado, G.; Bigcas, J.L.; Li, W. Galectin-3 is a new MerTK-specific eat-me signal. J. Cell. Physiol. 2012, 227, 401-407. [CrossRef] [PubMed]

35. Manfioletti, G.; Brancolini, C.; Avanzi, G.; Schneider, C. The protein encoded by a growth arrest-specific gene (gas6) is a new member of the vitamin K-dependent proteins related to protein S, a negative coregulator in the blood coagulation cascade. Mol. Cell. Biol. 1993, 13, 4976-4985. [CrossRef] [PubMed]

36. Lew, E.D.; Oh, J.; Burrola, P.G.; Lax, I.; Zagorska, A.; Traves, P.G.; Schlessinger, J.; Lemke, G. Differential TAM receptor-ligandphospholipid interactions delimit differential TAM bioactivities. eLife 2014, 3. [CrossRef]

37. Nagata, K.; Ohashi, K.; Nakano, T.; Arita, H.; Zong, C.; Hanafusa, H.; Mizuno, K. Identification of the product of growth arrest-specific gene 6 as a common ligand for Axl, Sky, and Mer receptor tyrosine kinases. J. Biol. Chem. 1996, 271 , 30022-30027. [CrossRef]

38. Kasikara, C.; Kumar, S.; Kimani, S.; Tsou, W.I.; Geng, K.; Davra, V.; Sriram, G.; Devoe, C.; Nguyen, K.N.; Antes, A.; et al. Phosphatidylserine Sensing by TAM Receptors Regulates AKT-Dependent Chemoresistance and PD-L1 Expression. Mol. Cancer Res. 2017, 15, 753-764. [CrossRef] [PubMed]

39. Tsou, W.I.; Nguyen, K.Q.; Calarese, D.A.; Garforth, S.J.; Antes, A.L.; Smirnov, S.V.; Almo, S.C.; Birge, R.B.; Kotenko, S.V. Receptor tyrosine kinases, TYRO3, AXL, and MER, demonstrate distinct patterns and complex regulation of ligand-induced activation. J. Biol. Chem. 2014, 289, 25750-25763. [CrossRef]

40. Crosier, P.S.; Freeman, S.A.; Orlic, D.; Bodine, D.M.; Crosier, K.E. The Dtk receptor tyrosine kinase, which binds protein S, is expressed during hematopoiesis. Exp. Hematol. 1996, 24, 318-323. 
41. Faust, M.; Ebensperger, C.; Schulz, A.S.; Schleithoff, L.; Hameister, H.; Bartram, C.R.; Janssen, J.W. The murine ufo receptor: Molecular cloning, chromosomal localization and in situ expression analysis. Oncogene 1992, 7, 1287-1293. [PubMed]

42. Lu, Q.; Lemke, G. Homeostatic regulation of the immune system by receptor tyrosine kinases of the Tyro 3 family. Science 2001, 293, 306-311. [CrossRef] [PubMed]

43. Scott, R.S.; McMahon, E.J.; Pop, S.M.; Reap, E.A.; Caricchio, R.; Cohen, P.L.; Earp, H.S.; Matsushima, G.K. Phagocytosis and clearance of apoptotic cells is mediated by MER. Nature 2001, 411, 207-211. [CrossRef]

44. Lu, Q.; Gore, M.; Zhang, Q.; Camenisch, T.; Boast, S.; Casagranda, F.; Lai, C.; Skinner, M.K.; Klein, R.; Matsushima, G.K.; et al. Tyro-3 family receptors are essential regulators of mammalian spermatogenesis. Nature 1999, 398, 723-728. [CrossRef] [PubMed]

45. Camenisch, T.D.; Koller, B.H.; Earp, H.S.; Matsushima, G.K. A novel receptor tyrosine kinase, Mer, inhibits TNF-alpha production and lipopolysaccharide-induced endotoxic shock. J. Immunol. 1999, 162, 3498-3503. [PubMed]

46. Caraux, A.; Lu, Q.; Fernandez, N.; Riou, S.; Di Santo, J.P.; Raulet, D.H.; Lemke, G.; Roth, C. Natural killer cell differentiation driven by Tyro3 receptor tyrosine kinases. Nat. Immunol. 2006, 7, 747-754. [CrossRef]

47. Rahman, Z.S.; Shao, W.H.; Khan, T.N.; Zhen, Y.; Cohen, P.L. Impaired apoptotic cell clearance in the germinal center by Merdeficient tingible body macrophages leads to enhanced antibody-forming cell and germinal center responses. J. Immunol. 2010, 185, 5859-5868. [CrossRef]

48. Cohen, P.L.; Caricchio, R.; Abraham, V.; Camenisch, T.D.; Jennette, J.C.; Roubey, R.A.; Earp, H.S.; Matsushima, G.; Reap, E.A. Delayed apoptotic cell clearance and lupus-like autoimmunity in mice lacking the c-mer membrane tyrosine kinase. J. Exp. Med. 2002, 196, 135-140. [CrossRef]

49. Angelillo-Scherrer, A.; Burnier, L.; Flores, N.; Savi, P.; DeMol, M.; Schaeffer, P.; Herbert, J.M.; Lemke, G.; Goff, S.P.; Matsushima, G.K.; et al. Role of Gas6 receptors in platelet signaling during thrombus stabilization and implications for antithrombotic therapy. J. Clin. Investig. 2005, 115, 237-246. [CrossRef]

50. Wallet, M.A.; Sen, P.; Flores, R.R.; Wang, Y.; Yi, Z.; Huang, Y.; Mathews, C.E.; Earp, H.S.; Matsushima, G.; Wang, B.; et al. MerTK is required for apoptotic cell-induced T cell tolerance. J. Exp. Med. 2008, 205, 219-232. [CrossRef]

51. Linger, R.M.; Cohen, R.A.; Cummings, C.T.; Sather, S.; Migdall-Wilson, J.; Middleton, D.H.; Lu, X.; Baron, A.E.; Franklin, W.A.; Merrick, D.T.; et al. Mer or Axl receptor tyrosine kinase inhibition promotes apoptosis, blocks growth and enhances chemosensitivity of human non-small cell lung cancer. Oncogene 2013, 32, 3420-3431. [CrossRef] [PubMed]

52. Wimmel, A.; Glitz, D.; Kraus, A.; Roeder, J.; Schuermann, M. Axl receptor tyrosine kinase expression in human lung cancer cell lines correlates with cellular adhesion. Eur. J. Cancer 2001, 37, 2264-2274. [CrossRef]

53. Zhang, Z.; Lee, J.C.; Lin, L.; Olivas, V.; Au, V.; LaFramboise, T.; Abdel-Rahman, M.; Wang, X.; Levine, A.D.; Rho, J.K.; et al. Activation of the AXL kinase causes resistance to EGFR-targeted therapy in lung cancer. Nat. Genet. 2012, 44, 852-860. [CrossRef] [PubMed]

54. Taniguchi, H.; Yamada, T.; Wang, R.; Tanimura, K.; Adachi, Y.; Nishiyama, A.; Tanimoto, A.; Takeuchi, S.; Araujo, L.H.; Boroni, M.; et al. AXL confers intrinsic resistance to osimertinib and advances the emergence of tolerant cells. Nat. Commun. 2019, 10, 259. [CrossRef] [PubMed]

55. Xie, S.; Li, Y.; Li, X.; Wang, L.; Yang, N.; Wang, Y.; Wei, H. Mer receptor tyrosine kinase is frequently overexpressed in human non-small cell lung cancer, confirming resistance to erlotinib. Oncotarget 2015, 6, 9206-9219. [CrossRef] [PubMed]

56. Iida, S.; Miki, Y.; Suzuki, T.; Mori, K.; Saito, M.; Niikawa, H.; Kondo, T.; Yamada-Okabe, H.; Sasano, H. Activation of AXL and antitumor effects of a monoclonal antibody to AXL in lung adenocarcinoma. Anticancer Res. 2014, 34, 1821-1827. [PubMed]

57. Qu, X.H.; Liu, J.L.; Zhong, X.W.; Li, X.I.; Zhang, Q.G. Insights into the roles of hnRNP A2/B1 and AXL in non-small cell lung cancer. Oncol. Lett. 2015, 10, 1677-1685. [CrossRef]

58. Wu, Z.; Bai, F.; Fan, L.; Pang, W.; Han, R.; Wang, J.; Liu, Y.; Yan, X.; Duan, H.; Xing, L. Coexpression of receptor tyrosine kinase AXL and EGFR in human primary lung adenocarcinomas. Hum. Pathol. 2015, 46, 1935-1944. [CrossRef] [PubMed]

59. Ramkumar, K.; Stewart, C.A.; Cargill, K.R.; Della Corte, C.M.; Wang, Q.; Shen, L.; Diao, L.; Cardnell, R.J.; Peng, D.H.; Rodriguez, B.L.; et al. AXL Inhibition Induces DNA Damage and Replication Stress in Non-Small Cell Lung Cancer Cells and Promotes Sensitivity to ATR Inhibitors. Mol. Cancer Res. 2021, 19, 485-497. [CrossRef] [PubMed]

60. Safaric Tepes, P.; Pal, D.; Lindsted, T.; Ibarra, I.; Lujambio, A.; Jimenez Sabinina, V.; Senturk, S.; Miller, M.; Korimerla, N.; Huang, J.; et al. An epigenetic switch regulates the ontogeny of AXL-positive/EGFR-TKi-resistant cells by modulating miR-335 expression. eLife 2021, 10. [CrossRef]

61. Shieh, Y.S.; Lai, C.Y.; Kao, Y.R.; Shiah, S.G.; Chu, Y.W.; Lee, H.S.; Wu, C.W. Expression of axl in lung adenocarcinoma and correlation with tumor progression. Neoplasia 2005, 7, 1058-1064. [CrossRef] [PubMed]

62. Ishikawa, M.; Sonobe, M.; Nakayama, E.; Kobayashi, M.; Kikuchi, R.; Kitamura, J.; Imamura, N.; Date, H. Higher expression of receptor tyrosine kinase Axl, and differential expression of its ligand, Gas6, predict poor survival in lung adenocarcinoma patients. Ann. Surg. Oncol. 2013, 20 (Suppl. 3), S467-S476. [CrossRef] [PubMed]

63. Melchionna, R.; Spada, S.; Di Modugno, F.; D'Andrea, D.; Di Carlo, A.; Panetta, M.; Mileo, A.M.; Sperduti, I.; Antoniani, B.; Gallo, E.; et al. The actin modulator hMENA regulates GAS6-AXL axis and pro-tumor cancer/stromal cell cooperation. EMBO Rep. 2020, 21, e50078. [CrossRef] [PubMed]

64. Li, Y.; Ye, X.; Tan, C.; Hongo, J.A.; Zha, J.; Liu, J.; Kallop, D.; Ludlam, M.J.; Pei, L. Axl as a potential therapeutic target in cancer: Role of Axl in tumor growth, metastasis and angiogenesis. Oncogene 2009, 28, 3442-3455. [CrossRef] [PubMed] 
65. Sato, K.; Suda, K.; Shimizu, S.; Sakai, K.; Mizuuchi, H.; Tomizawa, K.; Takemoto, T.; Nishio, K.; Mitsudomi, T. Clinical, Pathological, and Molecular Features of Lung Adenocarcinomas with AXL Expression. PLoS ONE 2016, 11, e0154186. [CrossRef]

66. Cummings, C.T.; Linger, R.M.; Cohen, R.A.; Sather, S.; Kirkpatrick, G.D.; Davies, K.D.; DeRyckere, D.; Earp, H.S.; Graham, D.K. Mer590, a novel monoclonal antibody targeting MER receptor tyrosine kinase, decreases colony formation and increases chemosensitivity in non-small cell lung cancer. Oncotarget 2014, 5, 10434-10445. [CrossRef]

67. Zhang, W.; DeRyckere, D.; Hunter, D.; Liu, J.; Stashko, M.A.; Minson, K.A.; Cummings, C.T.; Lee, M.; Glaros, T.G.; Newton, D.L.; et al. UNC2025, a potent and orally bioavailable MER/FLT3 dual inhibitor. J. Med. Chem. 2014, 57, 7031-7041. [CrossRef]

68. Cummings, C.T.; Zhang, W.; Davies, K.D.; Kirkpatrick, G.D.; Zhang, D.; DeRyckere, D.; Wang, X.; Frye, S.V.; Earp, H.S.; Graham, D.K. Small Molecule Inhibition of MERTK Is Efficacious in Non-Small Cell Lung Cancer Models Independent of Driver Oncogene Status. Mol. Cancer Ther. 2015, 14, 2014-2022. [CrossRef]

69. Yan, D.; Parker, R.E.; Wang, X.; Frye, S.V.; Earp, H.S., 3rd; DeRyckere, D.; Graham, D.K. MERTK Promotes Resistance to Irreversible EGFR Tyrosine Kinase Inhibitors in Non-small Cell Lung Cancers Expressing Wild-type EGFR Family Members. Clin. Cancer Res. 2018, 24, 6523-6535. [CrossRef]

70. Ye, X.; Li, Y.; Stawicki, S.; Couto, S.; Eastham-Anderson, J.; Kallop, D.; Weimer, R.; Wu, Y.; Pei, L. An anti-Axl monoclonal antibody attenuates xenograft tumor growth and enhances the effect of multiple anticancer therapies. Oncogene 2010, 29, 5254-5264. [CrossRef]

71. Aguilera, T.A.; Rafat, M.; Castellini, L.; Shehade, H.; Kariolis, M.S.; Hui, A.B.; Stehr, H.; von Eyben, R.; Jiang, D.; Ellies, L.G.; et al. Reprogramming the immunological microenvironment through radiation and targeting Axl. Nat. Commun. 2016, 7, 13898. [CrossRef]

72. Brand, T.M.; Iida, M.; Stein, A.P.; Corrigan, K.L.; Braverman, C.M.; Luthar, N.; Toulany, M.; Gill, P.S.; Salgia, R.; Kimple, R.J.; et al. AXL mediates resistance to cetuximab therapy. Cancer Res. 2014, 74, 5152-5164. [CrossRef] [PubMed]

73. Rho, J.K.; Choi, Y.J.; Kim, S.Y.; Kim, T.W.; Choi, E.K.; Yoon, S.J.; Park, B.M.; Park, E.; Bae, J.H.; Choi, C.M.; et al. MET and AXL inhibitor NPS-1034 exerts efficacy against lung cancer cells resistant to EGFR kinase inhibitors because of MET or AXL activation. Cancer Res. 2014, 74, 253-262. [CrossRef]

74. Wu, F.; Li, J.; Jang, C.; Wang, J.; Xiong, J. The role of Axl in drug resistance and epithelial-to-mesenchymal transition of non-small cell lung carcinoma. Int. J. Clin. Exp. Pathol. 2014, 7, 6653-6661. [PubMed]

75. Bae, S.Y.; Hong, J.Y.; Lee, H.J.; Park, H.J.; Lee, S.K. Targeting the degradation of AXL receptor tyrosine kinase to overcome resistance in gefitinib-resistant non-small cell lung cancer. Oncotarget 2015, 6, 10146-10160. [CrossRef] [PubMed]

76. Elkabets, M.; Pazarentzos, E.; Juric, D.; Sheng, Q.; Pelossof, R.A.; Brook, S.; Benzaken, A.O.; Rodon, J.; Morse, N.; Yan, J.J.; et al. AXL mediates resistance to PI3Kalpha inhibition by activating the EGFR/PKC/mTOR axis in head and neck and esophageal squamous cell carcinomas. Cancer Cell 2015, 27, 533-546. [CrossRef] [PubMed]

77. Sen, T.; Tong, P.; Diao, L.; Li, L.; Fan, Y.; Hoff, J.; Heymach, J.V.; Wang, J.; Byers, L.A. Targeting AXL and mTOR Pathway Overcomes Primary and Acquired Resistance to WEE1 Inhibition in Small-Cell Lung Cancer. Clin. Cancer Res. 2017, 23, 6239-6253. [CrossRef]

78. McDaniel, N.K.; Cummings, C.T.; Iida, M.; Hulse, J.; Pearson, H.E.; Vasileiadi, E.; Parker, R.E.; Orbuch, R.A.; Ondracek, O.J.; Welke, N.B.; et al. MERTK Mediates Intrinsic and Adaptive Resistance to AXL-targeting Agents. Mol. Cancer Ther. 2018, 17, 2297-2308. [CrossRef]

79. Nakamichi, S.; Seike, M.; Miyanaga, A.; Chiba, M.; Zou, F.; Takahashi, A.; Ishikawa, A.; Kunugi, S.; Noro, R.; Kubota, K.; et al. Overcoming drug-tolerant cancer cell subpopulations showing AXL activation and epithelial-mesenchymal transition is critical in conquering ALK-positive lung cancer. Oncotarget 2018, 9, 27242-27255. [CrossRef]

80. Yan, D.; Huelse, J.; Parker, R.; Tan, Z.; Wang, X.; Frye, S.V.; Earp, H.S.; DeRyckere, D.; Graham, D.K. MERTK drives residual tumor growth in EGFR-mutated non-small cell lung cancer cells treated with osimertinib. Cancer Res. 2020, 80. [CrossRef]

81. Yan, D.; Tan, Z.; Wang, X.; Frye, S.V.; Earp, H.S., III; DeRyckere, D.; Graham, D.K. A novel strategy to cope with osimertinib resistance in non-small cell lung cancer by treatment with a PIM kinase inhibitor in combination with a MERTK-selective kinase inhibitor. Cancer Res. 2021, 81. [CrossRef]

82. Okura, N.; Nishioka, N.; Yamada, T.; Taniguchi, H.; Tanimura, K.; Katayama, Y.; Yoshimura, A.; Watanabe, S.; Kikuchi, T.; Shiotsu, S.; et al. ONO-7475, a Novel AXL Inhibitor, Suppresses the Adaptive Resistance to Initial EGFR-TKI Treatment in EGFR-Mutated Non-Small Cell Lung Cancer. Clin. Cancer Res. 2020, 26, 2244-2256. [CrossRef] [PubMed]

83. Rios-Doria, J.; Favata, M.; Lasky, K.; Feldman, P.; Lo, Y.; Yang, G.; Stevens, C.; Wen, X.; Sehra, S.; Katiyar, K.; et al. A Potent and Selective Dual Inhibitor of AXL and MERTK Possesses Both Immunomodulatory and Tumor-Targeted Activity. Front. Oncol. 2020, 10, 598477. [CrossRef] [PubMed]

84. Wang, T.H.; Wu, C.C.; Huang, K.Y.; Leu, Y.L.; Yang, S.C.; Chen, C.L.; Chen, C.Y. Integrated Omics Analysis of Non-Small-Cell Lung Cancer Cells Harboring the EGFR C797S Mutation Reveals the Potential of AXL as a Novel Therapeutic Target in TKI-Resistant Lung Cancer. Cancers 2020, 13, 111. [CrossRef]

85. Konen, J.M.; Rodriguez, B.L.; Padhye, A.; Ochieng, J.K.; Gibson, L.; Diao, L.; Fowlkes, N.W.; Fradette, J.J.; Peng, D.H.; Cardnell, R.J.; et al. Dual Inhibition of MEK and AXL Targets Tumor Cell Heterogeneity and Prevents Resistant Outgrowth Mediated by the Epithelial-to-Mesenchymal Transition in NSCLC. Cancer Res. 2021, 81, 1398-1412. [CrossRef] 
86. Tirado-Gonzalez, I.; Descot, A.; Soetopo, D.; Nevmerzhitskaya, A.; Schaffer, A.; Czlonka, E.; Wachtel, C.; Tsoukala, I.; Muller, L. AXL Inhibition in Macrophages Stimulates Host-versus-Leukemia Immunity and Eradicates Naive and Treatment-Resistant Leukemia. Cancer Discov. 2021, 11. [CrossRef]

87. Wilson, C.; Ye, X.; Pham, T.; Lin, E.; Chan, S.; McNamara, E.; Neve, R.M.; Belmont, L.; Koeppen, H.; Yauch, R.L.; et al. AXL inhibition sensitizes mesenchymal cancer cells to antimitotic drugs. Cancer Res. 2014, 74, 5878-5890. [CrossRef]

88. Kim, K.C.; Baek, S.H.; Lee, C. Curcumin-induced downregulation of Axl receptor tyrosine kinase inhibits cell proliferation and circumvents chemoresistance in non-small lung cancer cells. Int. J. Oncol. 2015, 47, 2296-2303. [CrossRef]

89. Wang, C.; Jin, H.; Wang, N.; Fan, S.; Wang, Y.; Zhang, Y.; Wei, L.; Tao, X.; Gu, D.; Zhao, F.; et al. Gas6/Axl Axis Contributes to Chemoresistance and Metastasis in Breast Cancer through Akt/GSK-3beta/beta-catenin Signaling. Theranostics 2016, 6, 1205-1219. [CrossRef]

90. Shin, D.H.; Lee, H.J.; Min, H.Y.; Choi, S.P.; Lee, M.S.; Lee, J.W.; Johnson, F.M.; Mehta, K.; Lippman, S.M.; Glisson, B.S.; et al. Combating resistance to anti-IGFR antibody by targeting the integrin beta3-Src pathway. J. Natl. Cancer Inst. 2013, 105, 1558-1570. [CrossRef]

91. Huang, F.; Hurlburt, W.; Greer, A.; Reeves, K.A.; Hillerman, S.; Chang, H.; Fargnoli, J.; Graf Finckenstein, F.; Gottardis, M.M.; Carboni, J.M. Differential mechanisms of acquired resistance to insulin-like growth factor-i receptor antibody therapy or to a small-molecule inhibitor, BMS-754807, in a human rhabdomyosarcoma model. Cancer Res. 2010, 70, 7221-7231. [CrossRef] [PubMed]

92. Boshuizen, J.; Koopman, L.A.; Krijgsman, O.; Shahrabi, A.; van den Heuvel, E.G.; Ligtenberg, M.A.; Vredevoogd, D.W.; Kemper, K.; Kuilman, T.; Song, J.Y.; et al. Cooperative targeting of melanoma heterogeneity with an AXL antibody-drug conjugate and BRAF/MEK inhibitors. Nat. Med. 2018, 24, 203-212. [CrossRef] [PubMed]

93. Taverna, J.A.; Hung, C.N.; DeArmond, D.T.; Chen, M.; Lin, C.L.; Osmulski, P.A.; Gaczynska, M.E.; Wang, C.M.; Lucio, N.D.; Chou, C.W.; et al. Single-Cell Proteomic Profiling Identifies Combined AXL and JAK1 Inhibition as a Novel Therapeutic Strategy for Lung Cancer. Cancer Res. 2020, 80, 1551-1563. [CrossRef] [PubMed]

94. Graham, D.K.; Bowman, G.W.; Dawson, T.L.; Stanford, W.L.; Earp, H.S.; Snodgrass, H.R. Cloning and developmental expression analysis of the murine c-mer tyrosine kinase. Oncogene 1995, 10, 2349-2359. [PubMed]

95. Quong, R.Y.; Bickford, S.T.; Ing, Y.L.; Terman, B.; Herlyn, M.; Lassam, N.J. Protein kinases in normal and transformed melanocytes. Melanoma Res. 1994, 4, 313-319. [CrossRef] [PubMed]

96. Lee-Sherick, A.B.; Eisenman, K.M.; Sather, S.; McGranahan, A.; Armistead, P.M.; McGary, C.S.; Hunsucker, S.A.; Schlegel, J.; Martinson, H.; Cannon, C.; et al. Aberrant Mer receptor tyrosine kinase expression contributes to leukemogenesis in acute myeloid leukemia. Oncogene 2016, 35, 6270. [CrossRef] [PubMed]

97. Huey, M.G.; Minson, K.A.; Earp, H.S.; DeRyckere, D.; Graham, D.K. Targeting the TAM Receptors in Leukemia. Cancers 2016, 8, 101. [CrossRef]

98. Meric, F.; Lee, W.P.; Sahin, A.; Zhang, H.; Kung, H.J.; Hung, M.C. Expression profile of tyrosine kinases in breast cancer. Clin. Cancer Res. 2002, 8, 361-367.

99. Craven, R.J.; Xu, L.H.; Weiner, T.M.; Fridell, Y.W.; Dent, G.A.; Srivastava, S.; Varnum, B.; Liu, E.T.; Cance, W.G. Receptor tyrosine kinases expressed in metastatic colon cancer. Int. J. Cancer 1995, 60, 791-797. [CrossRef]

100. Tsou, A.P.; Wu, K.M.; Tsen, T.Y.; Chi, C.W.; Chiu, J.H.; Lui, W.Y.; Hu, C.P.; Chang, C.; Chou, C.K.; Tsai, S.F. Parallel hybridization analysis of multiple protein kinase genes: Identification of gene expression patterns characteristic of human hepatocellular carcinoma. Genomics 1998, 50, 331-340. [CrossRef]

101. Wu, C.W.; Li, A.F.; Chi, C.W.; Lai, C.H.; Huang, C.L.; Lo, S.S.; Lui, W.Y.; Lin, W.C. Clinical significance of AXL kinase family in gastric cancer. Anticancer Res. 2002, 22, 1071-1078. [PubMed]

102. Jacob, A.N.; Kalapurakal, J.; Davidson, W.R.; Kandpal, G.; Dunson, N.; Prashar, Y.; Kandpal, R.P. A receptor tyrosine kinase UFO/Axl, and other genes isolated by a modified differential display PCR are overexpressed in metastatic prostatic carcinoma cell line DU145. Cancer Detect. Prev. 1999, 23, 325-332. [CrossRef] [PubMed]

103. Wu, Y.M.; Robinson, D.R.; Kung, H.J. Signal pathways in up-regulation of chemokines by tyrosine kinase MER/NYK in prostate cancer cells. Cancer Res. 2004, 64, 7311-7320. [CrossRef] [PubMed]

104. Rankin, E.B.; Fuh, K.C.; Taylor, T.E.; Krieg, A.J.; Musser, M.; Yuan, J.; Wei, K.; Kuo, C.J.; Longacre, T.A.; Giaccia, A.J. AXL is an essential factor and therapeutic target for metastatic ovarian cancer. Cancer Res. 2010, 70, 7570-7579. [CrossRef]

105. Evans, C.O.; Young, A.N.; Brown, M.R.; Brat, D.J.; Parks, J.S.; Neish, A.S.; Oyesiku, N.M. Novel patterns of gene expression in pituitary adenomas identified by complementary deoxyribonucleic acid microarrays and quantitative reverse transcriptionpolymerase chain reaction. J. Clin. Endocrinol. Metab. 2001, 86, 3097-3107. [CrossRef]

106. Vajkoczy, P.; Knyazev, P.; Kunkel, A.; Capelle, H.H.; Behrndt, S.; von Tengg-Kobligk, H.; Kiessling, F.; Eichelsbacher, U.; Essig, M.; Read, T.A.; et al. Dominant-negative inhibition of the Axl receptor tyrosine kinase suppresses brain tumor cell growth and invasion and prolongs survival. Proc. Natl. Acad. Sci. USA 2006, 103, 5799-5804. [CrossRef]

107. Ling, L.; Kung, H.J. Mitogenic signals and transforming potential of Nyk, a newly identified neural cell adhesion molecule-related receptor tyrosine kinase. Mol. Cell. Biol. 1995, 15, 6582-6592. [CrossRef]

108. Lierman, E.; Van Miegroet, H.; Beullens, E.; Cools, J. Identification of protein tyrosine kinases with oncogenic potential using a retroviral insertion mutagenesis screen. Haematologica 2009, 94, 1440-1444. [CrossRef] 
109. Georgescu, M.M.; Kirsch, K.H.; Shishido, T.; Zong, C.; Hanafusa, H. Biological effects of c-Mer receptor tyrosine kinase in hematopoietic cells depend on the Grb2 binding site in the receptor and activation of NF-kappaB. Mol. Cell. Biol. 1999, 19, 1171-1181. [CrossRef]

110. Janssen, J.W.; Schulz, A.S.; Steenvoorden, A.C.; Schmidberger, M.; Strehl, S.; Ambros, P.F.; Bartram, C.R. A novel putative tyrosine kinase receptor with oncogenic potential. Oncogene 1991, 6, 2113-2120.

111. Vuoriluoto, K.; Haugen, H.; Kiviluoto, S.; Mpindi, J.P.; Nevo, J.; Gjerdrum, C.; Tiron, C.; Lorens, J.B.; Ivaska, J. Vimentin regulates EMT induction by Slug and oncogenic H-Ras and migration by governing Axl expression in breast cancer. Oncogene 2011, 30, 1436-1448. [CrossRef]

112. Byers, L.A.; Diao, L.; Wang, J.; Saintigny, P.; Girard, L.; Peyton, M.; Shen, L.; Fan, Y.; Giri, U.; Tumula, P.K.; et al. An epithelialmesenchymal transition gene signature predicts resistance to EGFR and PI3K inhibitors and identifies Axl as a therapeutic target for overcoming EGFR inhibitor resistance. Clin. Cancer Res. 2013, 19, 279-290. [CrossRef] [PubMed]

113. Balaji, K.; Vijayaraghavan, S.; Diao, L.; Tong, P.; Fan, Y.; Carey, J.P.; Bui, T.N.; Warner, S.; Heymach, J.V.; Hunt, K.K.; et al. AXL Inhibition Suppresses the DNA Damage Response and Sensitizes Cells to PARP Inhibition in Multiple Cancers. Mol. Cancer Res. 2017, 15, 45-58. [CrossRef] [PubMed]

114. Gjerdrum, C.; Tiron, C.; Hoiby, T.; Stefansson, I.; Haugen, H.; Sandal, T.; Collett, K.; Li, S.; McCormack, E.; Gjertsen, B.T.; et al. Axl is an essential epithelial-to-mesenchymal transition-induced regulator of breast cancer metastasis and patient survival. Proc. Natl. Acad. Sci. USA 2010, 107, 1124-1129. [CrossRef] [PubMed]

115. Heerboth, S.; Housman, G.; Leary, M.; Longacre, M.; Byler, S.; Lapinska, K.; Willbanks, A.; Sarkar, S. EMT and tumor metastasis. Clin. Transl. Med. 2015, 4, 6. [CrossRef] [PubMed]

116. Suda, K.; Tomizawa, K.; Fujii, M.; Murakami, H.; Osada, H.; Maehara, Y.; Yatabe, Y.; Sekido, Y.; Mitsudomi, T. Epithelial to mesenchymal transition in an epidermal growth factor receptor-mutant lung cancer cell line with acquired resistance to erlotinib. J. Thorac. Oncol. 2011, 6, 1152-1161. [CrossRef]

117. Sequist, L.V.; Waltman, B.A.; Dias-Santagata, D.; Digumarthy, S.; Turke, A.B.; Fidias, P.; Bergethon, K.; Shaw, A.T.; Gettinger, S.; Cosper, A.K.; et al. Genotypic and histological evolution of lung cancers acquiring resistance to EGFR inhibitors. Sci. Transl. Med. 2011, 3, 75ra26. [CrossRef]

118. Chen, T.; You, Y.; Jiang, H.; Wang, Z.Z. Epithelial-mesenchymal transition (EMT): A biological process in the development, stem cell differentiation, and tumorigenesis. J. Cell. Physiol. 2017, 232, 3261-3272. [CrossRef]

119. Thiery, J.P. Epithelial-mesenchymal transitions in tumour progression. Nat. Rev. Cancer 2002, 2, 442-454. [CrossRef]

120. Bansal, N.; Mishra, P.J.; Stein, M.; DiPaola, R.S.; Bertino, J.R. Axl receptor tyrosine kinase is up-regulated in metformin resistant prostate cancer cells. Oncotarget 2015, 6, 15321-15331. [CrossRef]

121. Debruyne, D.N.; Bhatnagar, N.; Sharma, B.; Luther, W.; Moore, N.F.; Cheung, N.K.; Gray, N.S.; George, R.E. ALK inhibitor resistance in $\mathrm{ALK}(\mathrm{F} 1174 \mathrm{~L})$-driven neuroblastoma is associated with AXL activation and induction of EMT. Oncogene 2016, 35, 3681-3691. [CrossRef] [PubMed]

122. Cichon, M.A.; Szentpetery, Z.; Caley, M.P.; Papadakis, E.S.; Mackenzie, I.C.; Brennan, C.H.; O’Toole, E.A. The receptor tyrosine kinase Axl regulates cell-cell adhesion and stemness in cutaneous squamous cell carcinoma. Oncogene 2014, 33, 4185-4192. [CrossRef] [PubMed]

123. Lay, J.D.; Hong, C.C.; Huang, J.S.; Yang, Y.Y.; Pao, C.Y.; Liu, C.H.; Lai, Y.P.; Lai, G.M.; Cheng, A.L.; Su, I.J.; et al. Sulfasalazine suppresses drug resistance and invasiveness of lung adenocarcinoma cells expressing AXL. Cancer Res. 2007, 67, 3878-3887. [CrossRef] [PubMed]

124. Tai, K.Y.; Shieh, Y.S.; Lee, C.S.; Shiah, S.G.; Wu, C.W. Axl promotes cell invasion by inducing MMP-9 activity through activation of NF-kappaB and Brg-1. Oncogene 2008, 27, 4044-4055. [CrossRef] [PubMed]

125. Prieto-Vila, M.; Takahashi, R.U.; Usuba, W.; Kohama, I.; Ochiya, T. Drug Resistance Driven by Cancer Stem Cells and Their Niche. Int. J. Mol. Sci. 2017, 18, 574. [CrossRef]

126. Lawson, D.A.; Bhakta, N.R.; Kessenbrock, K.; Prummel, K.D.; Yu, Y.; Takai, K.; Zhou, A.; Eyob, H.; Balakrishnan, S.; Wang, C.Y.; et al. Single-cell analysis reveals a stem-cell program in human metastatic breast cancer cells. Nature 2015, 526, 131-135. [CrossRef] [PubMed]

127. Eom, H.; Kaushik, N.; Yoo, K.C.; Shim, J.K.; Kwon, M.; Choi, M.Y.; Yoon, T.; Kang, S.G.; Lee, S.J. MerTK mediates STAT3-KRAS/SRCsignaling axis for glioma stem cell maintenance. Artif. Cells Nanomed. Biotechnol. 2018, 46, 87-95. [CrossRef] [PubMed]

128. Asiedu, M.K.; Beauchamp-Perez, F.D.; Ingle, J.N.; Behrens, M.D.; Radisky, D.C.; Knutson, K.L. AXL induces epithelial-tomesenchymal transition and regulates the function of breast cancer stem cells. Oncogene 2014, 33, 1316-1324. [CrossRef]

129. Cackowski, F.C.; Eber, M.R.; Rhee, J.; Decker, A.M.; Yumoto, K.; Berry, J.E.; Lee, E.; Shiozawa, Y.; Jung, Y.; Aguirre-Ghiso, J.A.; et al. Mer Tyrosine Kinase Regulates Disseminated Prostate Cancer Cellular Dormancy. J. Cell. Biochem. 2017, 118, 891-902. [CrossRef]

130. Jung, Y.; Decker, A.M.; Wang, J.; Lee, E.; Kana, L.A.; Yumoto, K.; Cackowski, F.C.; Rhee, J.; Carmeliet, P.; Buttitta, L.; et al Endogenous GAS6 and Mer receptor signaling regulate prostate cancer stem cells in bone marrow. Oncotarget 2016, 7, 25698-25711. [CrossRef]

131. Ling, L.; Templeton, D.; Kung, H.J. Identification of the major autophosphorylation sites of Nyk/Mer, an NCAM-related receptor tyrosine kinase. J. Biol. Chem. 1996, 271, 18355-18362. [CrossRef] [PubMed] 
132. Weinger, J.G.; Gohari, P.; Yan, Y.; Backer, J.M.; Varnum, B.; Shafit-Zagardo, B. In brain, Axl recruits Grb2 and the p85 regulatory subunit of PI3 kinase; in vitro mutagenesis defines the requisite binding sites for downstream Akt activation. J. Neurochem. 2008, 106, 134-146. [CrossRef] [PubMed]

133. Braunger, J.; Schleithoff, L.; Schulz, A.S.; Kessler, H.; Lammers, R.; Ullrich, A.; Bartram, C.R.; Janssen, J.W. Intracellular signaling of the Ufo/Axl receptor tyrosine kinase is mediated mainly by a multi-substrate docking-site. Oncogene 1997, 14, 2619-2631. [CrossRef] [PubMed]

134. Fridell, Y.W.; Jin, Y.; Quilliam, L.A.; Burchert, A.; McCloskey, P.; Spizz, G.; Varnum, B.; Der, C.; Liu, E.T. Differential activation of the Ras/extracellular-signal-regulated protein kinase pathway is responsible for the biological consequences induced by the Axl receptor tyrosine kinase. Mol. Cell. Biol. 1996, 16, 135-145. [CrossRef] [PubMed]

135. Goruppi, S.; Ruaro, E.; Varnum, B.; Schneider, C. Requirement of phosphatidylinositol 3-kinase-dependent pathway and Src for Gas6-Axl mitogenic and survival activities in NIH 3T3 fibroblasts. Mol. Cell. Biol. 1997, 17, 4442-4453. [CrossRef]

136. Rogers, A.E.; Le, J.P.; Sather, S.; Pernu, B.M.; Graham, D.K.; Pierce, A.M.; Keating, A.K. Mer receptor tyrosine kinase inhibition impedes glioblastoma multiforme migration and alters cellular morphology. Oncogene 2012, 31, 4171-4181. [CrossRef]

137. Besser, D.; Bromberg, J.F.; Darnell, J.E., Jr.; Hanafusa, H. A single amino acid substitution in the v-Eyk intracellular domain results in activation of Stat3 and enhances cellular transformation. Mol. Cell. Biol. 1999, 19, 1401-1409. [CrossRef]

138. Mahajan, N.P.; Whang, Y.E.; Mohler, J.L.; Earp, H.S. Activated tyrosine kinase Ack1 promotes prostate tumorigenesis: Role of Ack1 in polyubiquitination of tumor suppressor Wwox. Cancer Res. 2005, 65, 10514-10523. [CrossRef]

139. Ghosh, A.K.; Secreto, C.; Boysen, J.; Sassoon, T.; Shanafelt, T.D.; Mukhopadhyay, D.; Kay, N.E. The novel receptor tyrosine kinase Axl is constitutively active in B-cell chronic lymphocytic leukemia and acts as a docking site of nonreceptor kinases: Implications for therapy. Blood 2011, 117, 1928-1937. [CrossRef] [PubMed]

140. Komurov, K.; Padron, D.; Cheng, T.; Roth, M.; Rosenblatt, K.P.; White, M.A. Comprehensive mapping of the human kinome to epidermal growth factor receptor signaling. J. Biol. Chem. 2010, 285, 21134-21142. [CrossRef]

141. Zahuczky, G.; Kristof, E.; Majai, G.; Fesus, L. Differentiation and glucocorticoid regulated apopto-phagocytic gene expression patterns in human macrophages. Role of Mertk in enhanced phagocytosis. PLoS ONE 2011, 6, e21349. [CrossRef] [PubMed]

142. Behrens, E.M.; Gadue, P.; Gong, S.Y.; Garrett, S.; Stein, P.L.; Cohen, P.L. The mer receptor tyrosine kinase: Expression and function suggest a role in innate immunity. Eur. J. Immunol. 2003, 33, 2160-2167. [CrossRef]

143. Zizzo, G.; Hilliard, B.A.; Monestier, M.; Cohen, P.L. Efficient clearance of early apoptotic cells by human macrophages requires M2c polarization and MerTK induction. J. Immunol. 2012, 189, 3508-3520. [CrossRef]

144. Gautier, E.L.; Shay, T.; Miller, J.; Greter, M.; Jakubzick, C.; Ivanov, S.; Helft, J.; Chow, A.; Elpek, K.G.; Gordonov, S.; et al. Geneexpression profiles and transcriptional regulatory pathways that underlie the identity and diversity of mouse tissue macrophages. Nat. Immunol. 2012, 13, 1118-1128. [CrossRef] [PubMed]

145. Myers, K.V.; Amend, S.R.; Pienta, K.J. Targeting Tyro3, Axl and MerTK (TAM receptors): Implications for macrophages in the tumor microenvironment. Mol. Cancer 2019, 18, 94. [CrossRef]

146. Mahajan, N.P.; Earp, H.S. An SH2 domain-dependent, phosphotyrosine-independent interaction between Vav1 and the Mer receptor tyrosine kinase: A mechanism for localizing guanine nucleotide-exchange factor action. J. Biol. Chem. 2003, 278, 42596-42603. [CrossRef]

147. Crittenden, M.R.; Baird, J.; Friedman, D.; Savage, T.; Uhde, L.; Alice, A.; Cottam, B.; Young, K.; Newell, P.; Nguyen, C.; et al. Mertk on tumor macrophages is a therapeutic target to prevent tumor recurrence following radiation therapy. Oncotarget 2016, 7 , 78653-78666. [CrossRef] [PubMed]

148. Kodelja, V.; Muller, C.; Tenorio, S.; Schebesch, C.; Orfanos, C.E.; Goerdt, S. Differences in angiogenic potential of classically vs alternatively activated macrophages. Immunobiology 1997, 197, 478-493. [CrossRef]

149. Jetten, N.; Verbruggen, S.; Gijbels, M.J.; Post, M.J.; De Winther, M.P.; Donners, M.M. Anti-inflammatory M2, but not proinflammatory M1 macrophages promote angiogenesis in vivo. Angiogenesis 2014, 17, 109-118. [CrossRef]

150. Alciato, F.; Sainaghi, P.P.; Sola, D.; Castello, L.; Avanzi, G.C. TNF-alpha, IL-6, and IL-1 expression is inhibited by GAS6 in monocytes/macrophages. J. Leukoc. Biol. 2010, 87, 869-875. [CrossRef]

151. Kim, S.Y.; Lim, E.J.; Yoon, Y.S.; Ahn, Y.H.; Park, E.M.; Kim, H.S.; Kang, J.L. Liver X receptor and STAT1 cooperate downstream of Gas6/Mer to induce anti-inflammatory arginase 2 expression in macrophages. Sci. Rep. 2016, 6, 29673. [CrossRef]

152. Ito, K. Impact of post-translational modifications of proteins on the inflammatory process. Biochem. Soc. Trans. 2007, 35, 281-283. [CrossRef] [PubMed]

153. Covert, M.W.; Leung, T.H.; Gaston, J.E.; Baltimore, D. Achieving stability of lipopolysaccharide-induced NF-kappaB activation. Science 2005, 309, 1854-1857. [CrossRef]

154. Cook, R.S.; Jacobsen, K.M.; Wofford, A.M.; DeRyckere, D.; Stanford, J.; Prieto, A.L.; Redente, E.; Sandahl, M.; Hunter, D.M.; Strunk, K.E.; et al. MerTK inhibition in tumor leukocytes decreases tumor growth and metastasis. J. Clin. Investig. 2013, 123, 3231-3242. [CrossRef] [PubMed]

155. Ruffell, B.; Chang-Strachan, D.; Chan, V.; Rosenbusch, A.; Ho, C.M.; Pryer, N.; Daniel, D.; Hwang, E.S.; Rugo, H.S.; Coussens, L.M. Macrophage IL-10 blocks CD8+ T cell-dependent responses to chemotherapy by suppressing IL-12 expression in intratumoral dendritic cells. Cancer Cell 2014, 26, 623-637. [CrossRef] 
156. Cabezon, R.; Carrera-Silva, E.A.; Florez-Grau, G.; Errasti, A.E.; Calderon-Gomez, E.; Lozano, J.J.; Espana, C.; Ricart, E.; Panes, J.; Rothlin, C.V.; et al. MERTK as negative regulator of human T cell activation. J. Leukoc. Biol. 2015, 97, 751-760. [CrossRef] [PubMed]

157. Sen, P.; Wallet, M.A.; Yi, Z.; Huang, Y.; Henderson, M.; Mathews, C.E.; Earp, H.S.; Matsushima, G.; Baldwin, A.S., Jr.; Tisch, R.M. Apoptotic cells induce Mer tyrosine kinase-dependent blockade of NF-kappaB activation in dendritic cells. Blood 2007, 109, 653-660. [CrossRef]

158. Rothlin, C.V.; Ghosh, S.; Zuniga, E.I.; Oldstone, M.B.; Lemke, G. TAM receptors are pleiotropic inhibitors of the innate immune response. Cell 2007, 131, 1124-1136. [CrossRef]

159. Nakagawa, R.; Naka, T.; Tsutsui, H.; Fujimoto, M.; Kimura, A.; Abe, T.; Seki, E.; Sato, S.; Takeuchi, O.; Takeda, K.; et al. SOCS-1 participates in negative regulation of LPS responses. Immunity 2002, 17, 677-687. [CrossRef]

160. Lemke, G. Biology of the TAM receptors. Cold Spring Harb. Perspect. Biol. 2013, 5, a009076. [CrossRef]

161. Lumbroso, D.; Soboh, S.; Maimon, A.; Schif-Zuck, S.; Ariel, A.; Burstyn-Cohen, T. Macrophage-Derived Protein S Facilitates Apoptotic Polymorphonuclear Cell Clearance by Resolution Phase Macrophages and Supports Their Reprogramming. Front. Immunol. 2018, 9, 358. [CrossRef] [PubMed]

162. Zhou, Y.; Fei, M.; Zhang, G.; Liang, W.C.; Lin, W.; Wu, Y.; Piskol, R.; Ridgway, J.; McNamara, E.; Huang, H.; et al. Blockade of the Phagocytic Receptor MerTK on Tumor-Associated Macrophages Enhances P2X7R-Dependent STING Activation by Tumor-Derived cGAMP. Immunity 2020, 52, 357-373.e359. [CrossRef]

163. Scutera, S.; Fraone, T.; Musso, T.; Cappello, P.; Rossi, S.; Pierobon, D.; Orinska, Z.; Paus, R.; Bulfone-Paus, S.; Giovarelli, M. Survival and migration of human dendritic cells are regulated by an IFN-alpha-inducible Axl/Gas6 pathway. J. Immunol. 2009, 183, 3004-3013. [CrossRef]

164. Sharif, M.N.; Sosic, D.; Rothlin, C.V.; Kelly, E.; Lemke, G.; Olson, E.N.; Ivashkiv, L.B. Twist mediates suppression of inflammation by type I IFNs and Axl. J. Exp. Med. 2006, 203, 1891-1901. [CrossRef]

165. Yoshimura, A.; Nishinakamura, H.; Matsumura, Y.; Hanada, T. Negative regulation of cytokine signaling and immune responses by SOCS proteins. Arthritis Res. Ther. 2005, 7, 100-110. [CrossRef]

166. Mansell, A.; Smith, R.; Doyle, S.L.; Gray, P.; Fenner, J.E.; Crack, P.J.; Nicholson, S.E.; Hilton, D.J.; O’Neill, L.A.; Hertzog, P.J. Suppressor of cytokine signaling 1 negatively regulates Toll-like receptor signaling by mediating Mal degradation. Nat. Immunol. 2006, 7, 148-155. [CrossRef]

167. Zagorska, A.; Traves, P.G.; Lew, E.D.; Dransfield, I.; Lemke, G. Diversification of TAM receptor tyrosine kinase function. Nat. Immunol. 2014, 15, 920-928. [CrossRef]

168. Du, W.; Huang, H.; Sorrelle, N.; Brekken, R.A. Sitravatinib potentiates immune checkpoint blockade in refractory cancer models. JCI Insight 2018, 3, e124184. [CrossRef] [PubMed]

169. Paolino, M.; Penninger, J.M. The Role of TAM Family Receptors in Immune Cell Function: Implications for Cancer Therapy. Cancers 2016, 8, 97. [CrossRef]

170. Lee-Sherick, A.B.; Jacobsen, K.M.; Henry, C.J.; Huey, M.G.; Parker, R.E.; Page, L.S.; Hill, A.A.; Wang, X.; Frye, S.V.; Earp, H.S.; et al. MERTK inhibition alters the PD-1 axis and promotes anti-leukemia immunity. JCI Insight 2018, 3, e97941. [CrossRef] [PubMed]

171. Kasikara, C.; Davra, V.; Calianese, D.; Geng, K.; Spires, T.E.; Quigley, M.; Wichroski, M.; Sriram, G.; Suarez-Lopez, L.; Yaffe, M.B.; et al. Pan-TAM tyrosine kinase inhibitor BMS-777607 enhances anti-PD-1 mAb efficacy in a murine model of triple-negative breast cancer. Cancer Res. 2019, 79, 2669-2683. [CrossRef]

172. Tsukita, Y.; Fujino, N.; Miyauchi, E.; Saito, R.; Fujishima, F.; Itakura, K.; Kyogoku, Y.; Okutomo, K.; Yamada, M.; Okazaki, T.; et al. Axl kinase drives immune checkpoint and chemokine signalling pathways in lung adenocarcinomas. Mol. Cancer 2019, 18, 24. [CrossRef]

173. Terry, S.; Dalban, C.; Rioux Leclercq, N.; Adam, J.; Meylan, M.; Buart, S.; Bougouin, A.; Lespagnol, A.; Dugay, F.; Colina Moreno, I.; et al. Association of AXL and PD-L1 expression with clinical outcomes in patients with advanced renal cell carcinoma treated with PD-1 blockade. Clin. Cancer Res. 2021. [CrossRef]

174. Terry, S.; Abdou, A.; Engelsen, A.S.T.; Buart, S.; Dessen, P.; Corgnac, S.; Collares, D.; Meurice, G.; Gausdal, G.; Baud, V.; et al. AXL Targeting Overcomes Human Lung Cancer Cell Resistance to NK- and CTL-Mediated Cytotoxicity. Cancer Immunol. Res. 2019, 7, 1789-1802. [CrossRef]

175. Grabiec, A.M.; Goenka, A.; Fife, M.E.; Fujimori, T.; Hussell, T. Axl and MerTK receptor tyrosine kinases maintain human macrophage efferocytic capacity in the presence of viral triggers. Eur. J. Immunol. 2018, 48, 855-860. [CrossRef]

176. Seitz, H.M.; Camenisch, T.D.; Lemke, G.; Earp, H.S.; Matsushima, G.K. Macrophages and dendritic cells use different Axl/Mertk/Tyro3 receptors in clearance of apoptotic cells. J. Immunol. 2007, 178, 5635-5642. [CrossRef] [PubMed]

177. Di Virgilio, F.; Sarti, A.C.; Falzoni, S.; De Marchi, E.; Adinolfi, E. Extracellular ATP and P2 purinergic signalling in the tumour microenvironment. Nat. Rev. Cancer 2018, 18, 601-618. [CrossRef] [PubMed]

178. Pellegatti, P.; Raffaghello, L.; Bianchi, G.; Piccardi, F.; Pistoia, V.; Di Virgilio, F. Increased level of extracellular ATP at tumor sites: In vivo imaging with plasma membrane luciferase. PLoS ONE 2008, 3, e2599. [CrossRef]

179. Sun, L.; Wu, J.; Du, F.; Chen, X.; Chen, Z.J. Cyclic GMP-AMP synthase is a cytosolic DNA sensor that activates the type I interferon pathway. Science 2013, 339, 786-791. [CrossRef] [PubMed]

180. Surprenant, A.; Rassendren, F.; Kawashima, E.; North, R.A.; Buell, G. The cytolytic P2Z receptor for extracellular ATP identified as a P2X receptor (P2X7). Science 1996, 272, 735-738. [CrossRef] 
181. Savio, L.E.B.; de Andrade Mello, P.; da Silva, C.G.; Coutinho-Silva, R. The P2X7 Receptor in Inflammatory Diseases: Angel or Demon? Front. Pharmacol. 2018, 9, 52. [CrossRef] [PubMed]

182. Wu, J.; Sun, L.; Chen, X.; Du, F.; Shi, H.; Chen, C.; Chen, Z.J. Cyclic GMP-AMP is an endogenous second messenger in innate immune signaling by cytosolic DNA. Science 2013, 339, 826-830. [CrossRef] [PubMed]

183. Bianchi, B.R.; Lynch, K.J.; Touma, E.; Niforatos, W.; Burgard, E.C.; Alexander, K.M.; Park, H.S.; Yu, H.; Metzger, R.; Kowaluk, E.; et al. Pharmacological characterization of recombinant human and rat P2X receptor subtypes. Eur. J. Pharmacol. 1999, 376, 127-138. [CrossRef]

184. Wang, H.; Hu, S.; Chen, X.; Shi, H.; Chen, C.; Sun, L.; Chen, Z.J. cGAS is essential for the antitumor effect of immune checkpoint blockade. Proc. Natl. Acad. Sci. USA 2017, 114, 1637-1642. [CrossRef] [PubMed]

185. Tanvetyanon, T.; Gray, J.E.; Antonia, S.J. PD-1 checkpoint blockade alone or combined PD-1 and CTLA-4 blockade as immunotherapy for lung cancer? Expert Opin. Biol. Ther. 2017, 17, 305-312. [CrossRef]

186. Reck, M.; Rodriguez-Abreu, D.; Robinson, A.G.; Hui, R.; Csoszi, T.; Fulop, A.; Gottfried, M.; Peled, N.; Tafreshi, A.; Cuffe, S.; et al. Pembrolizumab versus Chemotherapy for PD-L1-Positive Non-Small-Cell Lung Cancer. N. Engl. J. Med. 2016, 375, $1823-1833$. [CrossRef]

187. Pao, W.; Miller, V.; Zakowski, M.; Doherty, J.; Politi, K.; Sarkaria, I.; Singh, B.; Heelan, R.; Rusch, V.; Fulton, L.; et al. EGF receptor gene mutations are common in lung cancers from "never smokers" and are associated with sensitivity of tumors to gefitinib and erlotinib. Proc. Natl. Acad. Sci. USA 2004, 101, 13306-13311. [CrossRef]

188. Maemondo, M.; Inoue, A.; Kobayashi, K.; Sugawara, S.; Oizumi, S.; Isobe, H.; Gemma, A.; Harada, M.; Yoshizawa, H.; Kinoshita, I.; et al. Gefitinib or chemotherapy for non-small-cell lung cancer with mutated EGFR. N. Engl. J. Med. 2010, 362, 2380-2388. [CrossRef]

189. Riely, G.J.; Pao, W.; Pham, D.; Li, A.R.; Rizvi, N.; Venkatraman, E.S.; Zakowski, M.F.; Kris, M.G.; Ladanyi, M.; Miller, V.A. Clinical course of patients with non-small cell lung cancer and epidermal growth factor receptor exon 19 and exon 21 mutations treated with gefitinib or erlotinib. Clin. Cancer Res. 2006, 12, 839-844. [CrossRef]

190. Jackman, D.M.; Yeap, B.Y.; Sequist, L.V.; Lindeman, N.; Holmes, A.J.; Joshi, V.A.; Bell, D.W.; Huberman, M.S.; Halmos, B.; Rabin, M.S.; et al. Exon 19 deletion mutations of epidermal growth factor receptor are associated with prolonged survival in non-small cell lung cancer patients treated with gefitinib or erlotinib. Clin. Cancer Res. 2006, 12, 3908-3914. [CrossRef]

191. Ogino, A.; Kitao, H.; Hirano, S.; Uchida, A.; Ishiai, M.; Kozuki, T.; Takigawa, N.; Takata, M.; Kiura, K.; Tanimoto, M. Emergence of epidermal growth factor receptor T790M mutation during chronic exposure to gefitinib in a non small cell lung cancer cell line. Cancer Res. 2007, 67, 7807-7814. [CrossRef]

192. Kobayashi, S.; Boggon, T.J.; Dayaram, T.; Janne, P.A.; Kocher, O.; Meyerson, M.; Johnson, B.E.; Eck, M.J.; Tenen, D.G.; Halmos, B. EGFR mutation and resistance of non-small-cell lung cancer to gefitinib. N. Engl. J. Med. 2005, 352, 786-792. [CrossRef] [PubMed]

193. Pao, W.; Miller, V.A.; Politi, K.A.; Riely, G.J.; Somwar, R.; Zakowski, M.F.; Kris, M.G.; Varmus, H. Acquired resistance of lung adenocarcinomas to gefitinib or erlotinib is associated with a second mutation in the EGFR kinase domain. PLoS Med. 2005, 2, e73. [CrossRef] [PubMed]

194. Balak, M.N.; Gong, Y.; Riely, G.J.; Somwar, R.; Li, A.R.; Zakowski, M.F.; Chiang, A.; Yang, G.; Ouerfelli, O.; Kris, M.G.; et al. Novel D761Y and common secondary T790M mutations in epidermal growth factor receptor-mutant lung adenocarcinomas with acquired resistance to kinase inhibitors. Clin. Cancer Res. 2006, 12, 6494-6501. [CrossRef]

195. Janne, P.A.; Yang, J.C.; Kim, D.W.; Planchard, D.; Ohe, Y.; Ramalingam, S.S.; Ahn, M.J.; Kim, S.W.; Su, W.C.; Horn, L.; et al. AZD9291 in EGFR inhibitor-resistant non-small-cell lung cancer. N. Engl. J. Med. 2015, 372, 1689-1699. [CrossRef] [PubMed]

196. Li, G.; Ma, Y.; Yu, M.; Li, X.; Chen, X.; Gao, Y.; Cheng, P.; Zhang, G.; Wang, X. Identification of Hub Genes and Small Molecule Drugs Associated with Acquired Resistance to Gefitinib in Non-Small Cell Lung Cancer. J. Cancer 2021, 12, 5286-5295. [CrossRef]

197. Namba, K.; Shien, K.; Takahashi, Y.; Torigoe, H.; Sato, H.; Yoshioka, T.; Takeda, T.; Kurihara, E.; Ogoshi, Y.; Yamamoto, H.; et al. Activation of AXL as a Preclinical Acquired Resistance Mechanism Against Osimertinib Treatment in EGFR-Mutant Non-Small Cell Lung Cancer Cells. Mol. Cancer Res. 2019, 17, 499-507. [CrossRef]

198. Kim, D.; Bach, D.H.; Fan, Y.H.; Luu, T.T.; Hong, J.Y.; Park, H.J.; Lee, S.K. AXL degradation in combination with EGFR-TKI can delay and overcome acquired resistance in human non-small cell lung cancer cells. Cell Death Dis. 2019, 10, 361. [CrossRef]

199. Wang, F.; Liu, X.; Boris, A. Bartholdy, Haiying Cheng, Balazs Halmos. Blockade of AXL activation overcomes acquired resistance to EGFR tyrosine kinase inhibition in non-small cell lung cancer. Transl. Cancer Res. 2019, 8, 4. [CrossRef]

200. Jimbo, T.; Hatanaka, M.; Komatsu, T.; Taira, T.; Kumazawa, K.; Maeda, N.; Suzuki, T.; Ota, M.; Haginoya, N.; Isoyama, T.; et al DS-1205b, a novel selective inhibitor of AXL kinase, blocks resistance to EGFR-tyrosine kinase inhibitors in a non-small cell lung cancer xenograft model. Oncotarget 2019, 10, 5152-5167. [CrossRef]

201. Giles, K.M.; Kalinowski, F.C.; Candy, P.A.; Epis, M.R.; Zhang, P.M.; Redfern, A.D.; Stuart, L.M.; Goodall, G.J.; Leedman, P.J. Axl mediates acquired resistance of head and neck cancer cells to the epidermal growth factor receptor inhibitor erlotinib. Mol. Cancer Ther. 2013, 12, 2541-2558. [CrossRef] [PubMed]

202. Li, D.; Ambrogio, L.; Shimamura, T.; Kubo, S.; Takahashi, M.; Chirieac, L.R.; Padera, R.F.; Shapiro, G.I.; Baum, A.; Himmelsbach, F.; et al. BIBW2992, an irreversible EGFR/HER2 inhibitor highly effective in preclinical lung cancer models. Oncogene 2008, 27, 4702-4711. [CrossRef] [PubMed] 
203. Engelman, J.A.; Zejnullahu, K.; Gale, C.M.; Lifshits, E.; Gonzales, A.J.; Shimamura, T.; Zhao, F.; Vincent, P.W.; Naumov, G.N.; Bradner, J.E.; et al. PF00299804, an irreversible pan-ERBB inhibitor, is effective in lung cancer models with EGFR and ERBB2 mutations that are resistant to gefitinib. Cancer Res. 2007, 67, 11924-11932. [CrossRef]

204. Li, D.; Shimamura, T.; Ji, H.; Chen, L.; Haringsma, H.J.; McNamara, K.; Liang, M.C.; Perera, S.A.; Zaghlul, S.; Borgman, C.L.; et al. Bronchial and peripheral murine lung carcinomas induced by T790M-L858R mutant EGFR respond to HKI-272 and rapamycin combination therapy. Cancer Cell 2007, 12, 81-93. [CrossRef] [PubMed]

205. Yu, H.A.; Arcila, M.E.; Rekhtman, N.; Sima, C.S.; Zakowski, M.F.; Pao, W.; Kris, M.G.; Miller, V.A.; Ladanyi, M.; Riely, G.J. Analysis of tumor specimens at the time of acquired resistance to EGFR-TKI therapy in 155 patients with EGFR-mutant lung cancers. Clin. Cancer Res. 2013, 19, 2240-2247. [CrossRef]

206. Yun, C.H.; Mengwasser, K.E.; Toms, A.V.; Woo, M.S.; Greulich, H.; Wong, K.K.; Meyerson, M.; Eck, M.J. The T790M mutation in EGFR kinase causes drug resistance by increasing the affinity for ATP. Proc. Natl. Acad. Sci. USA 2008, 105, 2070-2075. [CrossRef]

207. Hong, Y.S.; Jang, W.J.; Chun, K.S.; Jeong, C.H. Hsp90 inhibition by WK88-1 potently suppresses the growth of gefitinib-resistant H1975 cells harboring the T790M mutation in EGFR. Oncol. Rep. 2014, 31, 2619-2624. [CrossRef] [PubMed]

208. Walter, A.O.; Sjin, R.T.; Haringsma, H.J.; Ohashi, K.; Sun, J.; Lee, K.; Dubrovskiy, A.; Labenski, M.; Zhu, Z.; Wang, Z.; et al. Discovery of a mutant-selective covalent inhibitor of EGFR that overcomes T790M-mediated resistance in NSCLC. Cancer Discov. 2013, 3, 1404-1415. [CrossRef]

209. Bean, J.; Riely, G.J.; Balak, M.; Marks, J.L.; Ladanyi, M.; Miller, V.A.; Pao, W. Acquired resistance to epidermal growth factor receptor kinase inhibitors associated with a novel T854A mutation in a patient with EGFR-mutant lung adenocarcinoma. Clin. Cancer Res. 2008, 14, 7519-7525. [CrossRef]

210. Khan, N.A.; Mirshahidi, S.; Mirshahidi, H.R. A novel insertion mutation on exon 20 of epidermal growth factor receptor, conferring resistance to erlotinib. Case Rep. Oncol. 2014, 7, 491-496. [CrossRef]

211. Engelman, J.A.; Zejnullahu, K.; Mitsudomi, T.; Song, Y.; Hyland, C.; Park, J.O.; Lindeman, N.; Gale, C.M.; Zhao, X.; Christensen, J.; et al. MET amplification leads to gefitinib resistance in lung cancer by activating ERBB3 signaling. Science 2007, 316, 1039-1043. [CrossRef] [PubMed]

212. Bean, J.; Brennan, C.; Shih, J.Y.; Riely, G.; Viale, A.; Wang, L.; Chitale, D.; Motoi, N.; Szoke, J.; Broderick, S.; et al. MET amplification occurs with or without T790M mutations in EGFR mutant lung tumors with acquired resistance to gefitinib or erlotinib. Proc. Natl. Acad. Sci. USA 2007, 104, 20932-20937. [CrossRef]

213. Kubo, T.; Yamamoto, H.; Lockwood, W.W.; Valencia, I.; Soh, J.; Peyton, M.; Jida, M.; Otani, H.; Fujii, T.; Ouchida, M.; et al. MET gene amplification or EGFR mutation activate MET in lung cancers untreated with EGFR tyrosine kinase inhibitors. J. Int. Cancer 2009, 124, 1778-1784. [CrossRef] [PubMed]

214. Yano, S.; Wang, W.; Li, Q.; Matsumoto, K.; Sakurama, H.; Nakamura, T.; Ogino, H.; Kakiuchi, S.; Hanibuchi, M.; Nishioka, Y.; et al. Hepatocyte growth factor induces gefitinib resistance of lung adenocarcinoma with epidermal growth factor receptor-activating mutations. Cancer Res. 2008, 68, 9479-9487. [CrossRef] [PubMed]

215. Guix, M.; Faber, A.C.; Wang, S.E.; Olivares, M.G.; Song, Y.; Qu, S.; Rinehart, C.; Seidel, B.; Yee, D.; Arteaga, C.L.; et al. Acquired resistance to EGFR tyrosine kinase inhibitors in cancer cells is mediated by loss of IGF-binding proteins. J. Clin. Investig. 2008, 118, 2609-2619. [CrossRef] [PubMed]

216. Azuma, K.; Kawahara, A.; Sonoda, K.; Nakashima, K.; Tashiro, K.; Watari, K.; Izumi, H.; Kage, M.; Kuwano, M.; Ono, M.; et al. FGFR1 activation is an escape mechanism in human lung cancer cells resistant to afatinib, a pan-EGFR family kinase inhibitor. Oncotarget 2014, 5, 5908-5919. [CrossRef]

217. Lee, C.K.; Kim, S.; Lee, J.S.; Lee, J.E.; Kim, S.M.; Yang, I.S.; Kim, H.R.; Lee, J.H.; Kim, S.; Cho, B.C. Next-generation sequencing reveals novel resistance mechanisms and molecular heterogeneity in EGFR-mutant non-small cell lung cancer with acquired resistance to EGFR-TKIs. Lung Cancer 2017, 113, 106-114. [CrossRef]

218. Ohashi, K.; Sequist, L.V.; Arcila, M.E.; Moran, T.; Chmielecki, J.; Lin, Y.L.; Pan, Y.; Wang, L.; de Stanchina, E.; Shien, K.; et al. Lung cancers with acquired resistance to EGFR inhibitors occasionally harbor BRAF gene mutations but lack mutations in KRAS, NRAS, or MEK1. Proc. Natl. Acad. Sci. USA 2012, 109, E2127-E2133. [CrossRef]

219. Schrock, A.B.; Zhu, V.W.; Hsieh, W.S.; Madison, R.; Creelan, B.; Silberberg, J.; Costin, D.; Bharne, A.; Bonta, I.; Bosemani, T.; et al. Receptor Tyrosine Kinase Fusions and BRAF Kinase Fusions are Rare but Actionable Resistance Mechanisms to EGFR Tyrosine Kinase Inhibitors. J. Thorac. Oncol. 2018, 13, 1312-1323. [CrossRef]

220. de Bruin, E.C.; Cowell, C.; Warne, P.H.; Jiang, M.; Saunders, R.E.; Melnick, M.A.; Gettinger, S.; Walther, Z.; Wurtz, A.; Heynen, G.J.; et al. Reduced NF1 expression confers resistance to EGFR inhibition in lung cancer. Cancer Discov. 2014, 4, 606-619. [CrossRef]

221. Kim, S.M.; Yun, M.R.; Hong, Y.K.; Solca, F.; Kim, J.H.; Kim, H.J.; Cho, B.C. Glycolysis inhibition sensitizes non-small cell lung cancer with T790M mutation to irreversible EGFR inhibitors via translational suppression of Mcl-1 by AMPK activation. Mol. Cancer Ther. 2013, 12, 2145-2156. [CrossRef] [PubMed]

222. Ercan, D.; Zhou, W.; Yanagita, M.; Capelletti, M.; Rogers, A.; Xiao, Y.; Gray, N.S.; Janne, P.A. Amplification of ERK2 mediates resistance to the novel irreversible EGFR inhibitor WZ4002. Cancer Res. 2011, 71, 4736. [CrossRef]

223. Kim, S.M.; Kwon, O.J.; Hong, Y.K.; Kim, J.H.; Solca, F.; Ha, S.J.; Soo, R.A.; Christensen, J.G.; Lee, J.H.; Cho, B.C. Activation of IL-6R/JAK1/STAT3 signaling induces de novo resistance to irreversible EGFR inhibitors in non-small cell lung cancer with T790M resistance mutation. Mol. Cancer Ther. 2012, 11, 2254-2264. [CrossRef] 
224. Yao, Z.; Fenoglio, S.; Gao, D.C.; Camiolo, M.; Stiles, B.; Lindsted, T.; Schlederer, M.; Johns, C.; Altorki, N.; Mittal, V.; et al. TGF-beta IL-6 axis mediates selective and adaptive mechanisms of resistance to molecular targeted therapy in lung cancer. Proc. Natl. Acad. Sci. USA 2010, 107, 15535-15540. [CrossRef] [PubMed]

225. Song, L.; Smith, M.A.; Doshi, P.; Sasser, K.; Fulp, W.; Altiok, S.; Haura, E.B. Antitumor efficacy of the anti-interleukin-6 (IL-6) antibody siltuximab in mouse xenograft models of lung cancer. J. Thorac. Oncol. 2014, 9, 974-982. [CrossRef] [PubMed]

226. Piotrowska, Z.; Thress, K.S.; Mooradian, M.; Heist, R.S.; Azzoli, C.G.; Temel, J.S.; Rizzo, C.; Nagy, R.J.; Lanman, R.B.; Gettinger, S.N.; et al. MET amplification (amp) as a resistance mechanism to osimertinib. J. Clin. Oncol. 2017, 35, 9020. [CrossRef]

227. Papadimitrakopoulou, A.; Wu, Y.-L.; Han, J.-Y.; Ahn, M.-J.; Ramalingam, S.S.; John, T.; Okamoto, I.; Yang, J.C.-H.; Bulusu, K.C.; Laus, G.; et al. Analysis of resistance mechanisms to osimertinib in patients with EGFR T790M advanced NSCLC from the AURA3 study. Ann. Oncol. 2018, 29, VIII741. [CrossRef]

228. Ramalingam, S.S.; Cheng, Y.; Zhou, C.; Ohe, Y.; Imamura, F.; Cho, B.C.; Lin, M.-C.; Majem, M.; Shah, R.; Rukazenkov, Y.; et al. Mechanisms of acquired resistance to first-line osimertinib: Preliminary data from the phase III FLAURA study. Ann. Oncol. 2018, 29, VIII740. [CrossRef]

229. Oxnard, G.R.; Hu, Y.; Mileham, K.F.; Husain, H.; Costa, D.B.; Tracy, P.; Feeney, N.; Sholl, L.M.; Dahlberg, S.E.; Redig, A.J.; et al. Assessment of Resistance Mechanisms and Clinical Implications in Patients With EGFR T790M-Positive Lung Cancer and Acquired Resistance to Osimertinib. JAMA Oncol. 2018, 4, 1527-1534. [CrossRef]

230. Ramalingam, S.S.; Yang, J.C.; Lee, C.K.; Kurata, T.; Kim, D.W.; John, T.; Nogami, N.; Ohe, Y.; Mann, H.; Rukazenkov, Y.; et al. Osimertinib As First-Line Treatment of EGFR Mutation-Positive Advanced Non-Small-Cell Lung Cancer. J. Clin. Oncol. 2018, 36, 841-849. [CrossRef]

231. Yang, Z.; Yang, N.; Ou, Q.; Xiang, Y.; Jiang, T.; Wu, X.; Bao, H.; Tong, X.; Wang, X.; Shao, Y.W.; et al. Investigating Novel Resistance Mechanisms to Third-Generation EGFR Tyrosine Kinase Inhibitor Osimertinib in Non-Small Cell Lung Cancer Patients. Clin. Cancer Res. 2018, 24, 3097-3107. [CrossRef]

232. Oztan, A.; Fischer, S.; Schrock, A.B.; Erlich, R.L.; Lovly, C.M.; Stephens, P.J.; Ross, J.S.; Miller, V.; Ali, S.M.; Ou, S.I.; et al. Emergence of EGFR G724S mutation in EGFR-mutant lung adenocarcinoma post progression on osimertinib. Lung Cancer 2017, 111, 84-87. [CrossRef]

233. Fassunke, J.; Muller, F.; Keul, M.; Michels, S.; Dammert, M.A.; Schmitt, A.; Plenker, D.; Lategahn, J.; Heydt, C.; Bragelmann, J.; et al. Overcoming EGFR(G724S)-mediated osimertinib resistance through unique binding characteristics of second-generation EGFR inhibitors. Nat. Commun. 2018, 9, 4655. [CrossRef] [PubMed]

234. Offin, M.; Somwar, R.; Rekhtman, N.; Benayed, R.; Chang, J.C.; Plodkowski, A.; Lui, A.J.W.; Eng, J.; Rosenblum, M.; Li, B.T.; et al. Acquired ALK and RET Gene Fusions as Mechanisms of Resistance to Osimertinib in EGFR-Mutant Lung Cancers. JCO Precis. Oncol. 2018, 2. [CrossRef] [PubMed]

235. Klempner, S.J.; Bazhenova, L.A.; Braiteh, F.S.; Nikolinakos, P.G.; Gowen, K.; Cervantes, C.M.; Chmielecki, J.; Greenbowe, J.R.; Ross, J.S.; Stephens, P.J.; et al. Emergence of RET rearrangement co-existing with activated EGFR mutation in EGFR-mutated NSCLC patients who had progressed on first- or second-generation EGFR TKI. Lung Cancer 2015, 89, 357-359. [CrossRef] [PubMed]

236. Soria, J.C.; Ohe, Y.; Vansteenkiste, J.; Reungwetwattana, T.; Chewaskulyong, B.; Lee, K.H.; Dechaphunkul, A.; Imamura, F.; Nogami, N.; Kurata, T.; et al. Osimertinib in Untreated EGFR-Mutated Advanced Non-Small-Cell Lung Cancer. N. Engl. J. Med. 2018, 378, 113-125. [CrossRef]

237. Ramalingam, S.S.; Vansteenkiste, J.; Planchard, D.; Cho, B.C.; Gray, J.E.; Ohe, Y.; Zhou, C.; Reungwetwattana, T.; Cheng, Y.; Chewaskulyong, B.; et al. Overall Survival with Osimertinib in Untreated, EGFR-Mutated Advanced NSCLC. N. Engl. J. Med. 2020, 382, 41-50. [CrossRef]

238. Rosell, R.; Moran, T.; Queralt, C.; Porta, R.; Cardenal, F.; Camps, C.; Majem, M.; Lopez-Vivanco, G.; Isla, D.; Provencio, M.; et al. Screening for epidermal growth factor receptor mutations in lung cancer. N. Engl. J. Med. 2009, 361, 958-967. [CrossRef]

239. Cross, D.A.; Ashton, S.E.; Ghiorghiu, S.; Eberlein, C.; Nebhan, C.A.; Spitzler, P.J.; Orme, J.P.; Finlay, M.R.; Ward, R.A.; Mellor, M.J.; et al. AZD9291, an irreversible EGFR TKI, overcomes T790M-mediated resistance to EGFR inhibitors in lung cancer. Cancer Discov. 2014, 4, 1046-1061. [CrossRef]

240. Schoenfeld, A.J.; Chan, J.M.; Kubota, D.; Sato, H.; Rizvi, H.; Daneshbod, Y.; Chang, J.C.; Paik, P.K.; Offin, M.; Arcila, M.E.; et al. Tumor Analyses Reveal Squamous Transformation and Off-Target Alterations As Early Resistance Mechanisms to First-line Osimertinib in EGFR-Mutant Lung Cancer. Clin. Cancer Res. 2020, 26. [CrossRef]

241. Wang, R.; Yamada, T.; Kita, K.; Taniguchi, H.; Arai, S.; Fukuda, K.; Terashima, M.; Ishimura, A.; Nishiyama, A.; Tanimoto, A.; et al. Transient IGF-1R inhibition combined with osimertinib eradicates AXL-low expressing EGFR mutated lung cancer. Nat. Commun. 2020, 11, 4607. [CrossRef]

242. Minson, K.A.; Smith, C.C.; DeRyckere, D.; Libbrecht, C.; Lee-Sherick, A.B.; Huey, M.G.; Lasater, E.A.; Kirkpatrick, G.D.; Stashko, M.A.; Zhang, W.; et al. The MERTK/FLT3 inhibitor MRX-2843 overcomes resistance-conferring FLT3 mutations in acute myeloid leukemia. JCI Insight 2016, 1, e85630. [CrossRef] [PubMed]

243. Lee, H.J.; Pham, P.C.; Pei, H.; Lim, B.; Hyun, S.Y.; Baek, B.; Kim, B.; Kim, Y.; Kim, M.H.; Kang, N.W.; et al. Development of the phenylpyrazolo[3,4-d]pyrimidine-based, insulin-like growth factor receptor/Src/AXL-targeting small molecule kinase inhibitor. Theranostics 2021, 11, 1918-1936. [CrossRef] [PubMed]

244. Sharma, S.V.; Bell, D.W.; Settleman, J.; Haber, D.A. Epidermal growth factor receptor mutations in lung cancer. Nat. Rev. Cancer 2007, 7, 169-181. [CrossRef] [PubMed] 
245. Cai, Y.R.; Dong, Y.J.; Wu, H.B.; Yu, D.P.; Zhou, L.J.; Su, D.; Zhang, L.; Chen, X.J. Expression level of CRKL and AXL combined with exon 19 deletion in EGFR and ALK status confer differential prognosis of lung adenocarcinoma subtypes. Oncol. Lett. 2016, 12, 3312-3322. [CrossRef]

246. Wang, Q.; Yang, S.; Wang, K.; Sun, S.Y. MET inhibitors for targeted therapy of EGFR TKI-resistant lung cancer. J. Hematol. Oncol. 2019, 12, 63. [CrossRef]

247. Rotow, J.; Bivona, T.G. Understanding and targeting resistance mechanisms in NSCLC. Nat. Rev. Cancer 2017, 17, 637-658. [CrossRef]

248. Molina-Arcas, M.; Moore, C.; Rana, S.; van Maldegem, F.; Mugarza, E.; Romero-Clavijo, P.; Herbert, E.; Horswell, S.; Li, L.S.; Janes, M.R.; et al. Development of combination therapies to maximize the impact of KRAS-G12C inhibitors in lung cancer. Sci. Transl. Med. 2019, 11. [CrossRef]

249. Yokoyama, Y.; Lew, E.D.; Seelige, R.; Tindall, E.A.; Walsh, C.; Fagan, P.C.; Lee, J.Y.; Nevarez, R.; Oh, J.; Tucker, K.D.; et al. Immuno-oncological Efficacy of RXDX-106, a Novel TAM (TYRO3, AXL, MER) Family Small-Molecule Kinase Inhibitor. Cancer Res. 2019, 79, 1996-2008. [CrossRef]

250. Yu, H.; Liu, R.; Ma, B.; Li, X.; Yen, H.Y.; Zhou, Y.; Krasnoperov, V.; Xia, Z.; Zhang, X.; Bove, A.M.; et al. Axl receptor tyrosine kinase is a potential therapeutic target in renal cell carcinoma. Br. J. Cancer 2015, 113, 616-625. [CrossRef]

251. Leconet, W.; Larbouret, C.; Chardes, T.; Thomas, G.; Neiveyans, M.; Busson, M.; Jarlier, M.; Radosevic-Robin, N.; Pugniere, M.; Bernex, F.; et al. Preclinical validation of AXL receptor as a target for antibody-based pancreatic cancer immunotherapy. Oncogene 2014, 33, 5405-5414. [CrossRef]

252. Zhang, Y.X.; Knyazev, P.G.; Cheburkin, Y.V.; Sharma, K.; Knyazev, Y.P.; Orfi, L.; Szabadkai, I.; Daub, H.; Keri, G.; Ullrich, A. AXL is a potential target for therapeutic intervention in breast cancer progression. Cancer Res. 2008, 68, 1905-1915. [CrossRef]

253. Park, I.K.; Mishra, A.; Chandler, J.; Whitman, S.P.; Marcucci, G.; Caligiuri, M.A. Inhibition of the receptor tyrosine kinase Axl impedes activation of the FLT3 internal tandem duplication in human acute myeloid leukemia: Implications for Axl as a potential therapeutic target. Blood 2013, 121, 2064-2073. [CrossRef] [PubMed]

254. Kariolis, M.S.; Miao, Y.R.; Jones, D.S., 2nd; Kapur, S.; Mathews, I.I.; Giaccia, A.J.; Cochran, J.R. An engineered Axl 'decoy receptor' effectively silences the Gas6-Axl signaling axis. Nat. Chem. Biol. 2014, 10, 977-983. [CrossRef]

255. Cerchia, L.; Esposito, C.L.; Camorani, S.; Rienzo, A.; Stasio, L.; Insabato, L.; Affuso, A.; de Franciscis, V. Targeting Axl with an high-affinity inhibitory aptamer. Mol. Ther. 2012, 20, 2291-2303. [CrossRef] [PubMed]

256. Ahnert, J.R.; Taylor, M.H.; O’Reilly, E.M.; Zhang, J.; Doebele, R.C.; Ben, Y.; Sharp, L.L.; Boyle, W.J.; Chang, C.; Frey, G.; et al. A phase $1 / 2$ dose-escalation and expansion study of a conditionally active anti-AXL humanized monoclonal antibody (BA3011) in patients with advanced solid tumors. J. Clin. Oncol. 2018, 36, TPS12126. [CrossRef]

257. Sharp, L.L.; Chang, C.; Frey, G.; Wang, J.; Liu, H.; Xing, C.; Yalcin, S.; Walls, M.; Ben, Y.; Boyle, W.J.; et al. Abstract 827: Anti-tumor efficacy of BA3011, a novel Conditionally Active Biologic (CAB) anti-AXL-ADC. Cancer Res. 2018, 78. [CrossRef]

258. Bonifacio, L.; Dodds, M.; Prohaska, D.; Moss, A.; Giaccia, A.; Tabibiazar, R.; McIntyre, G. Target-Mediated Drug Disposition Pharmacokinetic/Pharmacodynamic Model-Informed Dose Selection for the First-in-Human Study of AVB-S6-500. Clin. Transl. Sci. 2020, 13, 204-211. [CrossRef] [PubMed]

259. Schepisi, G.; Conteduca, V.; Casadei, C.; Gurioli, G.; Rossi, L.; Galla, V.; Cursano, M.C.; Brighi, N.; Lolli, C.; Menna, C.; et al. Potential Application of Chimeric Antigen Receptor (CAR)-T Cell Therapy in Renal Cell Tumors. Front. Oncol. 2020, $10,565857$. [CrossRef]

260. Burbridge, M.F.; Bossard, C.J.; Saunier, C.; Fejes, I.; Bruno, A.; Leonce, S.; Ferry, G.; Da Violante, G.; Bouzom, F.; Cattan, V.; et al. S49076 is a novel kinase inhibitor of MET, AXL, and FGFR with strong preclinical activity alone and in association with bevacizumab. Mol. Cancer Ther. 2013, 12, 1749-1762. [CrossRef]

261. Schroeder, G.M.; An, Y.; Cai, Z.W.; Chen, X.T.; Clark, C.; Cornelius, L.A.; Dai, J.; Gullo-Brown, J.; Gupta, A.; Henley, B.; et al. Discovery of N-(4-(2-amino-3-chloropyridin-4-yloxy)-3-fluorophenyl)-4-ethoxy-1-(4-fluorophenyl)-2-oxo-1,2-dihydropyridine3-carboxamide (BMS-777607), a selective and orally efficacious inhibitor of the Met kinase superfamily. J. Med. Chem. 2009, 52, 1251-1254. [CrossRef]

262. Yan, S.B.; Peek, V.L.; Ajamie, R.; Buchanan, S.G.; Graff, J.R.; Heidler, S.A.; Hui, Y.H.; Huss, K.L.; Konicek, B.W.; Manro, J.R.; et al. LY2801653 is an orally bioavailable multi-kinase inhibitor with potent activity against MET, MST1R, and other oncoproteins, and displays anti-tumor activities in mouse xenograft models. Investig. New Drugs 2013, 31, 833-844. [CrossRef] [PubMed]

263. Beaulieu, N.; Sainte-Croix, H.; Bonfils, C.; Mannion, M.; Raeppel, S.; Isakovic, L.; Claridge, S.; Saavedra, O.; Raeppel, F.; Vaisburg, A.; et al. Abstract 930: Preclinical charaterization of MG516, a novel inhibitor of receptor tyrosine kinases involved in resistance to targeted therapies. Cancer Res. 2013, 73, 930.

264. Patyna, S.; Laird, A.D.; Mendel, D.B.; O’Farrell, A.M.; Liang, C.; Guan, H.; Vojkovsky, T.; Vasile, S.; Wang, X.; Chen, J.; et al. SU14813: A novel multiple receptor tyrosine kinase inhibitor with potent antiangiogenic and antitumor activity. Mol. Cancer Ther. 2006, 5, 1774-1782. [CrossRef]

265. Lee, H.J.; Jeng, Y.M.; Chen, Y.L.; Chung, L.; Yuan, R.H. Gas6/Axl pathway promotes tumor invasion through the transcriptional activation of Slug in hepatocellular carcinoma. Carcinogenesis 2014, 35, 769-775. [CrossRef] [PubMed]

266. Mita, M.; Gordon, M.; Rosen, L.; Kapoor, N.; Choy, G.; Redkar, S.; Taverna, P.; Oganesian, A.; Sahai, A.; Azab, M.; et al. Phase 1B study of amuvatinib in combination with five standard cancer therapies in adults with advanced solid tumors. Cancer Chemother. Pharmacol. 2014, 74, 195-204. [CrossRef] 
267. Dhillon, S. Gilteritinib: First Global Approval. Drugs 2019, 79, 331-339. [CrossRef]

268. Padda, S.; Neal, J.W.; Wakelee, H.A. MET inhibitors in combination with other therapies in non-small cell lung cancer. Transl. Lung Cancer Res. 2012, 1, 238-253. [CrossRef]

269. Liu, L.; Wang, Q.; Xie, C.; Xi, N.; Guo, Z.; Li, M.; Hou, X.; Xie, N.; Sun, M.; Li, J.; et al. Drug interaction of ningetinib and gefitinib involving CYP1A1 and efflux transporters in non-small cell lung cancer patients. Br. J. Clin. Pharmacol. 2021, 87, 2098-2110. [CrossRef] [PubMed]

270. Wunk-Lipinska, K.; Tiron, C.; Gausdal, G.; Sandal, T.; Frink, R.; Hinz, S.; Hellesøy, M.; Ahmed, L.; Haugen, H.; Liang, X.; et al. Abstract 1747: BGB324, a selective small molecule Axl kinase inhibitor to overcome EMT-associated drug resistance in carcinomas: Therapeutic rationale and early clinical studies. Cancer Res. 2014, 74. [CrossRef]

271. Wang, X.; Saso, H.; Iwamoto, T.; Xia, W.; Gong, Y.; Pusztai, L.; Woodward, W.A.; Reuben, J.M.; Warner, S.L.; Bearss, D.J.; et al. TIG1 promotes the development and progression of inflammatory breast cancer through activation of Axl kinase. Cancer Res. 2013, 73, 6516-6525. [CrossRef]

272. Novello, S.; Camps, C.; Grossi, F.; Mazieres, J.; Abrey, L.; Vernejoux, J.M.; Thall, A.; Patyna, S.; Usari, T.; Wang, Z.; et al. Phase II study of sunitinib in patients with non-small cell lung cancer and irradiated brain metastases. J. Thorac. Oncol. 2011, 6, 1260-1266. [CrossRef]

273. Qian, F.; Engst, S.; Yamaguchi, K.; Yu, P.; Won, K.A.; Mock, L.; Lou, T.; Tan, J.; Li, C.; Tam, D.; et al. Inhibition of tumor cell growth, invasion, and metastasis by EXEL-2880 (XL880, GSK1363089), a novel inhibitor of HGF and VEGF receptor tyrosine kinases. Cancer Res. 2009, 69, 8009-8016. [CrossRef] [PubMed]

274. Yakes, F.M.; Chen, J.; Tan, J.; Yamaguchi, K.; Shi, Y.; Yu, P.; Qian, F.; Chu, F.; Bentzien, F.; Cancilla, B.; et al. Cabozantinib (XL184), a novel MET and VEGFR2 inhibitor, simultaneously suppresses metastasis, angiogenesis, and tumor growth. Mol. Cancer Ther. 2011, 10, 2298-2308. [CrossRef] [PubMed]

275. Esposito, C.L.; Cerchia, L.; Catuogno, S.; De Vita, G.; Dassie, J.P.; Santamaria, G.; Swiderski, P.; Condorelli, G.; Giangrande, P.H.; de Franciscis, V. Multifunctional aptamer-miRNA conjugates for targeted cancer therapy. Mol. Ther. 2014, 22, $1151-1163$. [CrossRef]

276. Rankin, E.B.; Fuh, K.C.; Castellini, L.; Viswanathan, K.; Finger, E.C.; Diep, A.N.; LaGory, E.L.; Kariolis, M.S.; Chan, A.; Lindgren, D.; et al. Direct regulation of GAS6/AXL signaling by HIF promotes renal metastasis through SRC and MET. Proc. Natl. Acad. Sci. USA 2014, 111, 13373-13378. [CrossRef]

277. Kariolis, M.S.; Miao, Y.R.; Diep, A.; Nash, S.E.; Olcina, M.M.; Jiang, D.; Jones, D.S., 2nd; Kapur, S.; Mathews, I.I.; Koong, A.C.; et al. Inhibition of the GAS6/AXL pathway augments the efficacy of chemotherapies. J. Clin. Investig. 2017, 127, 183-198. [CrossRef] [PubMed]

278. Chen, H.J.; Mok, T.S.; Chen, Z.H.; Guo, A.L.; Zhang, X.C.; Su, J.; Wu, Y.L. Clinicopathologic and molecular features of epidermal growth factor receptor T790M mutation and c-MET amplification in tyrosine kinase inhibitor-resistant Chinese non-small cell lung cancer. Pathol. Oncol. Res. 2009, 15, 651-658. [CrossRef] [PubMed]

279. Yang, Y.M.; Jang, Y.; Lee, S.H.; Kang, B.; Lim, S.M. AXL/MET dual inhibitor, CB469, has activity in non-small cell lung cancer with acquired resistance to EGFR TKI with AXL or MET activation. Lung Cancer 2020, 146, 70-77. [CrossRef]

280. Feneyrolles, C.; Spenlinhauer, A.; Guiet, L.; Fauvel, B.; Dayde-Cazals, B.; Warnault, P.; Cheve, G.; Yasri, A. Axl kinase as a key target for oncology: Focus on small molecule inhibitors. Mol. Cancer Ther. 2014, 13, 2141-2148. [CrossRef]

281. Paolino, M.; Choidas, A.; Wallner, S.; Pranjic, B.; Uribesalgo, I.; Loeser, S.; Jamieson, A.M.; Langdon, W.Y.; Ikeda, F.; Fededa, J.P.; et al. The E3 ligase Cbl-b and TAM receptors regulate cancer metastasis via natural killer cells. Nature 2014, 507, 508-512. [CrossRef]

282. Wu, J.; Frady, L.N.; Bash, R.E.; Cohen, S.M.; Schorzman, A.N.; Su, Y.T.; Irvin, D.M.; Zamboni, W.C.; Wang, X.; Frye, S.V.; et al. MerTK as a therapeutic target in glioblastoma. Neuro-Oncology 2018, 20, 92-102. [CrossRef] [PubMed]

283. D'Cruz, P.M.; Yasumura, D.; Weir, J.; Matthes, M.T.; Abderrahim, H.; LaVail, M.M.; Vollrath, D. Mutation of the receptor tyrosine kinase gene Mertk in the retinal dystrophic RCS rat. Hum. Mol. Genet. 2000, 9, 645-651. [CrossRef]

284. Angelillo-Scherrer, A.; de Frutos, P.; Aparicio, C.; Melis, E.; Savi, P.; Lupu, F.; Arnout, J.; Dewerchin, M.; Hoylaerts, M.; Herbert, J.; et al. Deficiency or inhibition of Gas6 causes platelet dysfunction and protects mice against thrombosis. Nat. Med. 2001, 7, 215-221. [CrossRef] [PubMed]

285. Sather, S.; Kenyon, K.D.; Lefkowitz, J.B.; Liang, X.; Varnum, B.C.; Henson, P.M.; Graham, D.K. A soluble form of the Mer receptor tyrosine kinase inhibits macrophage clearance of apoptotic cells and platelet aggregation. Blood 2007, 109, 1026-1033. [CrossRef]

286. Branchford, B.R.; Stalker, T.J.; Law, L.; Acevedo, G.; Sather, S.; Brzezinski, C.; Wilson, K.M.; Minson, K.; Lee-Sherick, A.B.; Davizon-Castillo, P.; et al. The small-molecule MERTK inhibitor UNC2025 decreases platelet activation and prevents thrombosis. J. Thromb. Haemost. 2018, 16, 352-363. [CrossRef]

287. DeRyckere, D.; Lee-Sherick, A.B.; Huey, M.G.; Hill, A.A.; Tyner, J.W.; Jacobsen, K.M.; Page, L.S.; Kirkpatrick, G.G.; Eryildiz, F.; Montgomery, S.A.; et al. UNC2025, a MERTK Small-Molecule Inhibitor, Is Therapeutically Effective Alone and in Combination with Methotrexate in Leukemia Models. Clin. Cancer Res. 2017, 23, 1481-1492. [CrossRef] [PubMed] 